\title{
The synthetic peptide LyeTxl-b derived from Lycosa erythrognatha spider venom is cytotoxic to U-87 MG glioblastoma cells
}

\author{
Mostafa A. L. Abdel-Salam ${ }^{1} \cdot$ Juliana Carvalho-Tavares ${ }^{1} \cdot$ Kamila Sousa Gomes $^{2} \cdot$ Andrea Teixeira-Carvalho $^{3}$. \\ Gregory T. Kitten $^{4,6}$ • Johanna Nyffeler ${ }^{5}$ Felipe F. Dias ${ }^{6} \cdot$ Pablo V. Mendes dos Reis $^{2} \cdot$ Adriano M. C. Pimenta $^{2}$. \\ Marcel Leist $^{5} \cdot$ Maria Elena de Lima ${ }^{2,7}$. Elaine Maria de Souza-Fagundes ${ }^{1}$ (D)
}

\begin{abstract}
Antimicrobial peptides present a broad spectrum of therapeutic applications, including their use as anticancer peptides. These peptides have as target microbial, normal, and cancerous cells. The oncological properties of these peptides may occur by membranolytic mechanisms or non-membranolytics. In this work, we demonstrate for the first time the cytotoxic effects of the cationic alpha-helical antimicrobial peptide LyeTx I-b on glioblastoma lineage U87-MG. The anticancer property of this peptide was associated with a membranolytic mechanism. Loss of membrane integrity occurred after incubation with the peptide for $15 \mathrm{~min}$, as shown by trypan blue uptake, reduction of calcein-AM conversion, and LDH release. Morphological studies using scanning electron microscopy demonstrated disruption of the plasma membrane from cells treated with LyeTx I-b, including the formation of holes or pores. Transmission electron microscopy analyses showed swollen nuclei with mild DNA condensation, cell volume increase with an electron-lucent cytoplasm and organelle vacuolization, but without the rupture of nuclear or plasmatic membranes. Morphometric analyses revealed a high percentage of cells in necroptosis stages, followed by necrosis and apoptosis at lower levels. Necrostatin-1, a known inhibitor of necroptosis, partially protected the cells from the toxicity of the peptide in a concentration-dependent manner. Imaging flow cytometry confirmed that $59 \%$ of the cells underwent necroptosis after 3-h incubation with the peptide. It is noteworthy that LyeTx I-b showed only mild cytotoxicity against normal fibroblasts of human and monkey cell lines and low hemolytic activity in human erythrocytes. All data together point out the anticancer potential of this peptide.
\end{abstract}

Keywords Glioblastoma multiform · U-87 MG cells · Anticancer peptide · LyeTx I-b

\section{Abbreviations \\ Cryo-EM Cryo-electron microscopy \\ TEM Transmission electron microscope \\ SEM Scanning electron microscope}

5 In Vitro Toxicology and Biomedicine, Department of Biology, University of Konstanz, Konstanz, Baden-Württemberg, Germany

Elaine Maria de Souza-Fagundes
elainefagundes@gmail.com; elainefagundes@ufmg.br

1 Departamento de Fisiologia e Biofísica, Instituto de Ciências Biológicas, Universidade Federal de Minas Gerais, Belo Horizonte, Minas Gerais, Brazil

2 Departamento de Bioquimia e Imunologia, Instituto de Ciências Biológicas, Universidade Federal de Minas Gerais, Belo Horizonte, Minas Gerais, Brazil

3 Laboratório de Biomarcadores de Diagnóstico e Monitoramento, Centro de Pesquisas René Rachou, Belo Horizonte, Minas Gerais, Brazil

4 Departamento de Morfologia, Instituto de Ciências Biológicas, Universidade Federal de Minas Gerais, Belo Horizonte, Minas Gerais, Brazil
6 Centro de Microscopia, Universidade Federal de Minas Gerais, Belo Horizonte, Minas Gerais, Brazil

7 Programa de Pós-graduação em Ciências da Saúde, Biomedicina e Medicina, Instituto de Ensino e Pesquisa da Santa Casa de Belo Horizonte, Grupo Santa Casa de Belo Horizonte, Belo Horizonte, Minas Gerais, Brazil 


$\begin{array}{ll}\text { Nec-1 } & \text { Necrostatin } \\ \text { GBM } & \text { Glioblastoma multiform } \\ \text { RIPK1 } & \text { Receptor interacting protein kinas-1 } \\ \text { TNF } & \text { Tumor necrosis factor } \\ \text { CAMPs } & \text { Cationic antimicrobial peptides } \\ \text { LDH } & \text { Lactate dehydrogenase } \\ \text { PBMC } & \text { Peripheral blood mononuclear cell }\end{array}$

\section{Introduction}

In spite of abundant efforts by researchers and clinicians in the neuro-oncology field to treat patients with glioblastoma multiform (GBM), there is still a very poor clinical outcome (Esmaeili et al. 2018). Among brain cancers, glioblastoma comprises one of the most aggressive and lethal malignant brain tumors due to apoptosis resistance, intolerable side effects of chemotherapy, and incomplete surgical remove surgical resection (Mellinghoff and Gilbertson 2017; William et al. 2018).

Arthropod venoms are rich in small peptides $(>10 \mathrm{kDa})$, being many of them toxins that target a variety of different proteins, such as receptors, ion channels, and enzymes, from preys and predators. Most of the lethal toxins found in these venoms are, in fact, peptides able to block or modulate ion channels in a myriad of cell surfaces (Pineda et al. 2014). Since the role of many different ion channels in cancer pathophysiology has become evident, ion channel toxins from spiders and scorpions have been proposed to be used as anticancer peptides (Bubien et al. 2004; Wang and Wang 2016; Nicoletti et al. 2017), as molecular probes to elucidate the functional aspects of these channels in cancer progression and migration (Rooj et al. 2012; Aissaoui et al. 2018) or chemically engineered to be used as tumor imaging agent in both diagnoses and prognoses (Aroui et al. 2015; Moore et al. 2013; Cohen-Inbar and Zaaroor 2016). New drugs aiming at overcoming resistance through the activation of other mechanisms of cell death, like necroptosis, are currently being investigated. Necroptosis, an alternative programmed cell death mechanism, originally described as an accidental cell death, is now known to be a regulated process similar to apoptosis, but it is caspase-independent (Su et al. 2016). Necroptosis is triggered by several types of stimuli, including abnormal cellular metabolism, activation of receptors by ligands such as tumor necrosis factor-TNF, interferon, Toll-like receptor ligands, and anticancer substances. The most well-studied mechanism is triggered by TNF, through recruitment of RIPK1 (receptor interacting protein kinase 1) and inhibition of caspase 8 (Su et al. 2016; Sun et al. 2018). RIPK1 has important kinase-dependent and scaffolding functions that inhibit or trigger necroptosis resulting in expulsion of cellular contents to the extracellular space (Galluzzi et al. 2011). In addition, morphological features of necroptosis are characterized by nucleus swelling, mild DNA condensation, and increased permeability of lysosomal and plasma membranes (Su et al. 2016). Necroptosis can also be induced after treatment with chemotherapeutic agents (Xu et al. 2017; Galluzzi et al. 2011). Thus, induction of necroptosis could be a promising therapeutic strategy to overcome drug resistance (Su et al. 2016; Pasparakis and Vandenabeele 2015). Cationic anticancer peptides have recently emerged as a new class of promising anticancer reagents owing to their lytic nature and ability to cause rapid cell membrane disruption. Therefore, it is important to test these peptides for their ability to reduce glioblastoma multiform resistance (Liu et al. 2013; Wei et al. 2017).

In this context, we synthetized a cationic peptide, LyeTx I-b, based on a peptide isolated from the venom of Lycosa erythrognatha spider. This peptide showed strong antimicrobial activity against Gram-positive and negative bacteria including planktonic and multispecies biofilms of periodontal pathogens under various conditions with slight hemolytic activity (Santos et al. 2010; Reis et al. 2018; Cruz Olivo et al. 2017). LyeTxI-b is a synthetic 24-mer peptide (IWLTALKFLGKNLGKLAKQQLAKL-NH2), which comprises a His 16 deletion and N-terminal acetylation, resulting in an improved effect against resistant bacteria. In addition, NMR data revealed that LyeTxI-b adopts a slightly curved helical structure, spanning from the second amino acid residue to its amidated C-terminus, without having, however, an obvious amphipathic secondary structure (Reis et al. 2018). To demonstrate the anticancer potential of this peptide, we focused on its cytotoxic activity against brain tumor cells, investigating its mechanism of action on glioma cells (U-87 MG), compared to non-tumoral human cells, as well as morphological studies using scanning and electronic microscopy, supported necroptosis as the main mechanism triggered by the peptide. Our findings permitted to characterize the cytotoxicity and the anticancer potential of the antimicrobial peptide LyeTx I-b.

\section{Materials and methods}

\section{Peptide}

The peptide LyeTx I-b was synthesized by GenOne (Rio de Janeiro, RJ, Brazil) and purified (98\%) using HPLC. The samples were maintained at $-80^{\circ} \mathrm{C}$ and solubilized in PBS immediately before the experiments.

\section{Cell lines}

Human glioblastoma U-87 MG and neuroblastoma SHSY5Y cells were kindly donated by Dr. Marcel Leist/University of Konstanz, Germany; Astrocytoma U-373 MG cells were donated by Dr. Rodrigo Resende, Federal University of Minas 
Gerais; VERO (African green monkey kidney epithelial cells) and GM-637 (human fibroblast) cells lines were used as a model of normal cells and were kindly provided by Dr. Erna Kroon and Adriana Abalen (Federal University of Minas Gerais). Cells were maintained in culture in DMEM high glucose medium enriched with $2 \mathrm{mM}$ L-glutamine (GIBCO UK, Grand Island, NY), $1 \%$ antibiotic solution (100 IU $/ \mathrm{ml}$ penicillin and $100 \mu \mathrm{g} / \mathrm{ml}$ streptomycin (GIBCO BRL, Grand Island, NY) and supplemented with $10 \%$ fetal bovine serum. All lineages were incubated at $37{ }^{\circ} \mathrm{C}$ in a humidified atmosphere containing $5 \% \mathrm{CO}_{2}$, and split twice weekly. The cells were regularly examined and used until 20 passages. Human peripheral blood mononuclear cells (PBMC) were obtained from six healthy donors. About $30 \mathrm{ml}$ of blood was collected from each individual in heparinized tubes. This project was approved by the UFMG Ethics in Research Committee (COEP), under protocol number 666.658/2016.

\section{MTT cell viability assay}

U-87 MG, U-373 MG, SHSY5Y, GM637, and Vero cells were plated at 1 or $2 \times 10^{4}$ cells/well in a 96-well/plate in $100 \mu \mathrm{l}$ DMEM complete medium and allowed to adhere for $24 \mathrm{~h}$ at $37{ }^{\circ} \mathrm{C}$ with $5 \% \mathrm{CO}_{2}$. After treatment of the various lineages for $48 \mathrm{~h}$ in the presence or the absence of the peptide, $2.5 \mathrm{mg} / \mathrm{ml}$ of MTT (Sigma ${ }^{\circledR}$ Co., USA) $(30 \mu \mathrm{l} / \mathrm{well})$ were added. The plates were incubated for $4 \mathrm{~h}$ at $37^{\circ} \mathrm{C}$ with $5 \% \mathrm{CO}_{2}$ until formation of formazan crystals. The supernatant was carefully removed using a syringe needle coupled with a suction pump to preserve crystals, and then, $200 \mu \mathrm{l}$ of $0.04(4 \mathrm{mM}) \mathrm{HCl}$ in isopropanol were added. After stirring gently for $5 \mathrm{~min}$ at room temperature, absorbance of solubilized MTT formazan product was measured at $595 \mathrm{~nm}$ on an ELISA reader (Spectramax-Molecular Devices ${ }^{\circledR}$ ) (Mosmann 1983). The results were expressed as percentage of the viable cells with the $y$-axis values relative to the control (PBS), considered as having $100 \%$ viability. The $\mathrm{IC}_{50}$ values were calculated by nonlinear or linear regression using the GraphPad Prism ${ }^{\circledR}$ Version 5.01 software.

\section{Resazurin cell viability assay}

PBMC from 6 healthy individuals were isolated by Ficoll paque gradient separation solution centrifugation lymphocyte separation medium "LSM", Organon Teknika, Durham, NC (Gomes et al. 2003). The cells were washed with RPMI 1640 medium and cultured in flat-bottom 96-well plates (Nunc). Proliferative responses were evaluated by incubating $2.5 \times 10^{5}$ cells/well in the presence or the absence of the peptide or phytohemagglutinin $(2.5 \mu \mathrm{g} / \mathrm{ml})$ at a final volume of $200 \mu \mathrm{l}$ of complete RPMI-1640 (10\% FBS, $2 \mathrm{mM} \mathrm{L-glu-}$ tamine, $100 \mathrm{IU} / \mathrm{ml}$ penicillin, and $100 \mu \mathrm{g} / \mathrm{ml}$ streptomycin). Incubation was carried out in a humidified $5 \% \mathrm{CO}_{2}$ incubator at $37^{\circ} \mathrm{C}$ for 3 days for PHA-stimulated cultures. Peptide was added using eight 1:2 serial dilutions $(100-1.56 \mu \mathrm{M})$ for $\mathrm{IC}_{50}$ determination. Cell viability was evaluated by the resazurin assay (O'Brien et al. 2000). The solution containing resazurin was blue, and when added to a cell culture, it is converted to the reduced pink and fluorescent form, resorufin, which can be measured by spectrophotometric reading of the absorbance at 570 and $600 \mathrm{~nm}$ in a plate reader (SpectramaxMolecular Devices ${ }^{\circledR}$ ). The number of viable cells was correlated with the percentage reduction of resazurin and was expressed as \% inhibition.

\section{Hemolytic activity}

Briefly, $1 \mathrm{ml}$ of fresh peripheral blood from 5 healthy volunteers was mixed with $400 \mu \mathrm{l}$ of heparin $(5000 \mathrm{IU} / \mathrm{ml})$ and centrifuged at $1200 \mathrm{rpm}$ for $10 \mathrm{~min}$ at room temperature. The red blood cells (RBC) were washed three times with sterile PBS and prepared as a 1\% (v/v) suspension of erythrocytes in PBS. $190 \mu \mathrm{l}$ of diluted RBCs were seeded in a 96-well plate with $10 \mu \mathrm{l}$ of LyeTx I-b at concentrations ranging from 100 to $1.56 \mu \mathrm{M}$ in the experimental groups, with $100 \mu \mathrm{l}$ of $2 \%(\mathrm{v} / \mathrm{v})$ Triton X-100 diluted in PBS in the positive control group, or with $10 \mu \mathrm{l}$ of PBS in the negative control group. After incubation at $37^{\circ} \mathrm{C}$ for $1 \mathrm{~h}$, samples were centrifuged at $1200 \mathrm{rpm}$ for $5 \mathrm{~min}$, and then, $150 \mu \mathrm{l}$ were transferred from each well to a new 96 wells/plate and the absorbance was measured at $450 \mathrm{~nm}$ using (SpectramaxMolecular Devices ${ }^{\circledR}$ ) a microplate reader (Yu et al. 2011). The percentage of hemolysis was calculated as:

$\begin{aligned} \text { Hemolysis } \%= & {[(\text { Sample absorbance }- \text { negative control }) /} \\ & (\text { positive control }- \text { negative control })] 100 \% .\end{aligned}$

\section{Investigation of the cell death mechanism induced by LyeTx I-b in U-87 MG cells}

\section{Quantification of DNA and cell-cycle analysis by flow cytometry}

Quantification of the DNA content and cell-cycle analysis was performed by flow cytometry (Nicoletti et al. 1991). 1 or $2 \times 10^{5} \mathrm{U}-87 \mathrm{MG}$ cells were seeded in 24-well plates and incubated overnight at $37^{\circ} \mathrm{C}$ for stabilization. U-87 MG cells were then incubated with $30 \mu \mathrm{M}$ LyeTx I-b for $24 \mathrm{~h}$. After treatment, the cells were transferred into $1 \mathrm{ml}$ tubes after trypsinization and centrifuged at 10,000 rpm for $5 \mathrm{~min}$ in a microcentrifuge (Denver Instrument Company, USA). The supernatant was discarded and $300 \mu \mathrm{l}$ of a hypotonic fluoro-chromic solution (HFS) containing $50 \mu \mathrm{g} / \mathrm{ml}$ of Propidium Iodide-IP (Sigma, Saint Louis, Missouri USA) and $0.1 \%$ of Triton X-100 (Sigma, Saint Louis, Missouri USA) in $0.1 \%$ sodium citrate (Sigma, Saint Louis, Missouri 
USA) was added. Plates were incubated for $4 \mathrm{~h}$ at $4{ }^{\circ} \mathrm{C}$. After incubation, the samples were submitted to flow cytometry analysis. The FL2 voltage was adjusted, so that the G0/G1 and $\mathrm{G} 2 / \mathrm{M}$ phases formed peaks of values of 200 and 400 , respectively, in FL2-A. The values of FSC-H, SSC-H, FL2A, and FL2-W were acquired for histograms and statistics analyses in the FlowJo 7.6.4 ${ }^{\circledR}$ program.

\section{Analysis of DNA fragmentation by agarose gel electrophoresis}

Profiles of DNA fragmentation were verified by $1.5 \%$ agarose gel electrophoresis to observe the typical apoptosis profile with the formation of bands containing multiples of 180-200 bp "ladder standard" (Wlodkowic et al. 2011). U-87 MG cells were grown in 6 well plates at 300,000 cells/ well for 24 h. $30 \mu \mathrm{M}$ LyeTx1-b was added and the plate was incubated again for $24 \mathrm{~h}$ in a $\mathrm{CO}_{2}$ incubator at $37^{\circ} \mathrm{C}$. DNA extraction was performed after this treatment period as described (Grimberg et al. 1989), and DNA quantity was determined by reading absorbance at $260 \mathrm{~nm}$ in NanoDrop apparatus (Thermo Scientific, USA). Electrophoresis was conducted in TAE- $1 \times$ buffer at $100 \mathrm{~V}$ and $500 \mathrm{~mA}$, and subsequently, the gel was stained with ethidium bromide solution $(0.5 \mu \mathrm{g} / \mathrm{ml})$ and photographed using a trans-illuminator.

\section{Quantification of autophagic cells}

Detection of autophagic vesicles in U-87 MG cells was labeled with acridine orange dye, which is commonly used to study autophagy. The U-87 MG cells were seeded at the density of 200,000 cells/well in 24-well plates and incubated at $37{ }^{\circ} \mathrm{C}$ overnight in a $\mathrm{CO}_{2}$ incubator. After this period, treatment with substances or negative control (PBS) was performed for $24 \mathrm{~h}$. Cells were washed with ice-cold PBS, and then labeled with $10 \mu \mathrm{g} / \mathrm{ml}$ acridine orange solution (Sigma Aldrich) prepared in Milli-Q water. After 10 min of incubation at room temperature, the cells were collected (as above) and read using a flow cytometer (Kanematsu et al. 2010).

\section{Cell death analysis with imaging flow cytometry}

U-87 MG cells $\left(3 \times 10^{5}\right.$ cells $)$ were seeded into each well of a 6 well/plate and cultured until reaching $80 \%$ confluence. Cell death was induced by adding LyeTx I-b for 3, 6 , and $12 \mathrm{~h}$. Cells were trypsinized, carefully suspended in the medium, transferred to microfuge tubes, centrifuged at $1200 \times g$ for $5 \mathrm{~min}$ at $4{ }^{\circ} \mathrm{C}$ and the supernatant then aspirated. Cells were washed with $1 \mathrm{ml}$ PBS and resuspended in $100 \mu \mathrm{l}$ staining buffer (BD Annexin V FITC Assay) by mixing $2.5 \mu \mathrm{l}$ of Annexin $\mathrm{V}$ and $2.5 \mu \mathrm{l}$ propidium iodide (PI) in the incubation buffer according to manufacturer's instructions. The cells were incubated for $15 \mathrm{~min}$ at room temperature and protected from light. Samples were immediately analyzed by Amnis ${ }^{\circledR}$ Imaging Flow Cytometry according to Analysis of Apoptosis and Necroptosis by Fluorescence-Activated Cell Sorting (Wallberg et al. 2016; Pietkiewicz et al. 2015).

\section{Lactate dehydrogenase enzyme activity}

U-87 MG cells were plated and the effect of the LyeTx I-b on the release of LDH enzyme was evaluated at 15,30, and 60 min after treatment. Lactate production was determined by assaying the formation of NADH and pyruvate from lactate in the presence of excess NAD ${ }^{+}$(Meira et al. 2005). The reaction is catalyzed by lactate dehydrogenase, the lactate concentration being calculated from the extinction coefficient of NADH at $340 \mathrm{~nm}$. $50 \mathrm{mM}$ sodium phosphate buffer ( $\mathrm{pH}$ 7.4) was prepared with $0.6 \mathrm{mM}$ sodium pyruvate. $6.3 \mathrm{mM}$ NADH solution was prepared at the time of use and protected from light and added immediately prior to reading. The LDH reaction was monitored after 30 min of reaction with reading absorbance at $340 \mathrm{~nm}$ in a Varioskan TM Flash spectrophotometer (Thermo Scientific). As a positive control, Triton X-100 (0.5\%) was used, and ultrapure water was as the negative control. For the calculation of the percentage of lysis, cells treated with Triton X-100 were considered as 100\% lysis (Chan et al. 2013).

\section{Quantification of the effect of Necrostatin-1 inhibitor on the viability of U-87 MG treated with the peptide}

Briefly, U-87 MG cells $\left(5 \times 10^{3} /\right.$ well $)$ were seeded into 96-well plates and pre-incubated with $(100 \mu \mathrm{M})$ Necrostatin-1 for $1 \mathrm{~h}$. The peptide was added in different concentrations and Triton X-100 $(0.1,0.05$, and $0.025 \% \mathrm{v} / \mathrm{v})$, and was used as a positive control (that induces necrosis). After $24 \mathrm{~h}$ of treatment, cell viability was evaluated by resazurin metabolism assay (Gartlon et al. 2006).

\section{Evaluation of U-87 MG cell membrane integrity after treatment with the peptide using trypan blue exclusion}

Briefly, after 15, 30, 60, 120, and $180 \mathrm{~min}$ of incubation of $1 \times 10^{4} \mathrm{U}-87 \mathrm{MG}$ cells per well (96 well plate) with $30 \mu \mathrm{M}$ LyeTx I-b, $20 \mu$ of $0.2 \%$ trypan blue in PBS were added and incubated for $5 \mathrm{~min}$ at room temperature, and then, cells were examined under a microscope. Only dead cells take up the dye and appear as darkly stained cells (Simon and Langdon 2003). 


\section{Morphological alteration analysis using time-lapse microscopy}

The same field of U-87 MG cells was imaged every $10 \mathrm{~min}$ during a 180 min treatment period with $30 \mu \mathrm{M}$ LyeTx I-b using a $20 \times$ objective on an Axio Observer.Z1 microscope (Zeiss, Oberkochen, Germany) equipped with an Axiocam MRm camera and an incubation system for a constant temperature and $\mathrm{CO}_{2}$ level.

\section{Time course using high-content automated imaging microscopy (Cellomics) to evaluate early events}

$\mathrm{U}-87 \mathrm{MG}$ cells were treated with $30 \mu \mathrm{M}$ of peptide or Triton $0.1 \%$ (positive control of necrosis) for $15 \mathrm{~min}$, labeled with Calcein/AM and Hoechst 3342, and then analyzed using a Cellomics system according to the manufactures protocols.

\section{Electron microscopic ultrastructural analysis of cryofixed, freeze-substituted cells}

To U-87 MG detached after peptide treatment, the control and treated cells were trypsinized, centrifuged at $960 \times g$ at room temperature for $5 \mathrm{~min}$, resuspended in DMEM medium supplemented with $0.1 \%$ FBS in microfuge tubes, and then allowed to recover in the incubator for $2 \mathrm{~h}$. The cells were centrifuged and resuspended in DMEM medium without serum, and the cell count determined using a hemocytometer. The suspension was divided into 4 groups: one control, untreated group and three groups treated with LyeTx I-b for $30 \mathrm{~min}, 1 \mathrm{~h}$ and $3 \mathrm{~h}$, respectively, in a water bath at $37{ }^{\circ} \mathrm{C}$. After each incubation period, cells were centrifuged at $960 \times g$ at room temperature for $5 \mathrm{~min}$, the supernatant was discarded, and $5 \mu \mathrm{l}(\sim 9000$ cells) from the pellet of each group were immediately mixed with sterile PBS or cryoprotectant (20\% dextran) and cryofixed by high-pressure freezing (HPF) in a Leica EM HPM100 (Leica Microsystems, Wetzlar, Germany). Ultrarapid cryofixation methods were used to preserve the plasma membrane in as close to the native state as possible. Samples were also evaluated using standard EM fixatives and similar results were obtained (data not shown). Cryofixed samples were stored in liquid nitrogen $\left(196{ }^{\circ} \mathrm{C}\right)$ overnight and then transferred to $2.0 \mathrm{ml}$ cryotubes containing liquid nitrogen above a $1.0 \mathrm{ml}$ frozen mixture of $1 \%$ osmium tetroxide in anhydrous acetone. Freeze substitution was carried out in a Leica EM AFS2, starting at $-90^{\circ} \mathrm{C}$ and slowly warming up to $20^{\circ} \mathrm{C}$ over a 4 day period. During freeze substitution, frozen water was removed from the samples by anhydrous acetone at a temperature low enough to prevent the cellular water from recrystallizing (Thompson et al. 2016; Zabeo et al. 2017). Samples were brought to room temperature and then processed for light, transmission, and scanning electron microscopy using standard techniques.

\section{Morphometric analyses of cryofixed samples}

High-resolution images of 300-nm-thick sections of cryofixed cells were captured at $1000 \times$ using a Zeiss Axio Imager Z2 with the Zen 2 Blue Edition V1.0 software (Carl Zeiss Microscopy GmbH, Jena, Germany). Images from different experiments $(n=4)$ were randomly collected to distinguish the different cell death processes and then subjected to morphometric analyses. For each group, a total of 200 cells were counted. The identification of glioblastoma cells was based on the presence of typical cell features such as normal round euchromatic nucleus as well as intact plasma and nuclear membranes. Cell death processes were characterized as: (a) apoptosis: clearly identified by its high toluidine blue affinity and morphological changes such as cell and nuclear shrinkage, chromatin condensation, membrane budding, and apoptotic bodies formation; (b) necroptosis: low toluidine blue affinity, swollen nucleus, increased cell volume, with intact or disarranged plasma and nuclear membranes; and (c) necrosis: loss of plasma membrane integrity and consequent cytoplasmic content leakage.

\section{Scanning electron microscope (SEM)}

Scanning electron micrographs of U-87 MG cells ranging in magnification from $10,000 \times$ to $20,000 \times$ and showing most of the cell surface were randomly taken from cryofixed, freeze-substituted samples, and membrane structure alterations like slits, pores, or hole formations were analyzed.

\section{Transmission electron microscopy (TEM)}

To study the cytoplasmic ultrastructural features of U-87 MG glioma cells and of the different cell death processes, a total of $80 \mathrm{U}-87 \mathrm{MG}$ electron micrographs ranging from $4200 \times$ to $26,500 \times$ and showing the cell profile and nucleus were randomly taken from the cryofixed cells. The same characteristics as visualized in the high-resolution light microscopy images were analyzed at the ultrastructural level, including the organelles organization within glioma cells.

\section{Statistical analysis}

For all parameters, data from different groups were compared by the Mann-Whitney $U$ test or one-way ANOVA followed by Kruskal-Wallis test, using the GraphPad Prism ${ }^{\circledR}$ 6.01 software (San Diego, CA, USA). 


\section{Results}

\section{Cytotoxicity of LyeTx I-b peptide against tumor and non-tumoral cell lines}

The cytotoxicity of LyeTx I-b peptide was evaluated against three cell lines representative of brain tumors: U-87 MG (glioblastoma), U373-MG (astrocytoma), and SHSY5Y (neuroblastoma). The $\mathrm{IC}_{50}$ values of the peptide for each cell line are shown in Table 1. LyeTx I-b demonstrated a different potency against each cell line: U-87 MG and U373-MG were more susceptible with $\mathrm{IC}_{50}$ values $<30 \mu \mathrm{M}$ ) as compared to SHSY5Y $(93 \mu \mathrm{M})$. General toxicity of the peptide was also evaluated against human PBMC, erythrocytes, fibroblast (GM637), and kidney cells (Vero). While non-tumor cells such as GM637 and Vero cells showed higher values of $\mathrm{IC}_{50}(>100 \mu \mathrm{M})$, human PBMC displayed lower $\mathrm{IC}_{50}$ values (Table 1). LyeTx I-b induced mild hemolytic activity, displaying 30-35\% hemolysis of human erythrocytes even at the highest concentration of the peptide $(100 \mu \mathrm{M})$, as shown in Table 1.

\section{The increase of subdiploid DNA content after expose to LyeTx I-b peptide is not associated with apoptosis}

To understand the mechanism of cytotoxicity induced by LyeTx I-b against brain tumor cells in vitro, we investigated the effect of the peptide on U-87 MG cells. Cell death mechanisms involved in the cytotoxicity of many anticancer drugs include apoptosis, autophagy, necrosis, and necroptosis among others. To evaluate if apoptosis was involved, the subdiploid DNA content of U-87 MG cells treated with

Table 1 IC50 value of LyeTxI_b cytotoxicity against cancer and normal cell lines

\begin{tabular}{ll}
\hline Cell line & LyeTxI_b IC $_{50}(\mu \mathrm{M})$ \\
\hline U87-MG & $29.20 \pm 7.96$ \\
U373-MG & $20.94 \pm 5.18$ \\
SHSY5Y & $93.80 \pm 2.17$ \\
GM637 & $\geq 100$ \\
Vero & $\geq 100$ \\
PBMC & $4.16 \pm 1.94$ \\
hRBC & $155 \pm 13.04$ \\
\hline
\end{tabular}

Cytotoxicity of LyeTx I-b peptide against neuronal cancer cells and non-tumoral cells. The $\mathrm{IC}_{50}$ values were calculated from the linear regression of the dose-log response curves after $48 \mathrm{~h}$ exposure to peptide, determined by the MTT and resazurin assays. Values are mean \pm SD; U-87 MG: Glioblastoma, U-373 MG: Astrocytoma, SHSY5Y: Neuroblastoma, GM637: human lung fibroblasts, Vero: African green monkey kidney, PBMC: Peripheral Blood Mononuclear Cells and hRBC: human blood red cells. The peptide was tested in erythrocytes from the peripheral blood of five different donors their $\mathrm{IC}_{25}$ and $\mathrm{IC}_{50}$ concentrations of peptide (10 and $30 \mu \mathrm{M}$, respectively) was measured by flow cytometry after a $24 \mathrm{~h}$ treatment. Cells undergoing apoptotic cell death display an increase of subdiploid DNA content, which can be associated with the DNA fragmentation induced during late apoptosis or necrosis. The histograms in Fig. 1A show a significant, concentration-dependent, increase in the percentage of subdiploid (Sub-G1) content in U-87 MG cells after treatment with $\mathrm{IC}_{50}$ concentrations of LyeTx I-b as compared with control (PBS). To confirm if the increase of the DNA content correlated with DNA fragmentation, agarose gel electrophoresis was performed to evaluate genomic DNA. Results in Fig. 1B display the profile of genomic DNA of U-87 MG cells after treatment with the $\mathrm{IC}_{25}$ concentration $(30 \mu \mathrm{M})$ of LyeTx I-b, and no DNA fragmentation ladder pattern was observed for treated or untreated control cells (i.e., DNA ladders of 180-200-bp oligomers are usually displayed in apoptotic cells). This observation indicates that the DNA fragmentation observed in U-87 MG cells after treatment with LyeTx I-b was not associated with apoptosis.

\section{Evaluation of autophagy induction by LyeTx I-b in U-87 MG cells}

To identify if autophagy was involved in the toxicity of the peptide, the autophagic acidic cellular compartments were evaluated by FACS using acridine orange-staining dye. The U-87 MG cells were treated with the same concentrations used to quantify the DNA content 10 and $30 \mu \mathrm{M}$ LyeTx I-b. Flow cytometric analysis of untreated U-87 MG cells after acridine orange staining showed that most of the cells were labeled with green fluorescence and a minimal red fluorescence $(4.37 \%)$. Similarly, after treatment with the peptide, the cells still exhibited a green fluorescence comparable to the control, and showed a discreet increase in red fluorescence (14.4\%), indicating the presence of acidic vesicle organelles (AVO), which characterizes autophagy. These data suggest that this cell death is not the principal mechanism that contributes to the cytotoxicity of LyeTx I-b on U-87 MG cells (Fig. 2).

\section{LyeTx I-b peptide induces rapid loss of cell membrane integrity of U-87 MG cells associated with morphological alterations}

Since the results up to this point demonstrated that LyeTx I-b peptide does not induce apoptosis or autophagy on U-87 MG cells, we investigated the involvement of necrosis, in cell membrane integrity and cell morphology. For that, time kinetics experiments were performed using MTT with $\mathrm{IC}_{50}$ $(30 \mu \mathrm{M})$. The results in Fig. 3A indicate that U-87 MG cells lose cell viability very quickly in the presence of $30 \mu \mathrm{M}$ LyeTx I-b (i.e., only after 15 min of treatment), as observed 
$A$
$\vdots$
$\vdots$
0

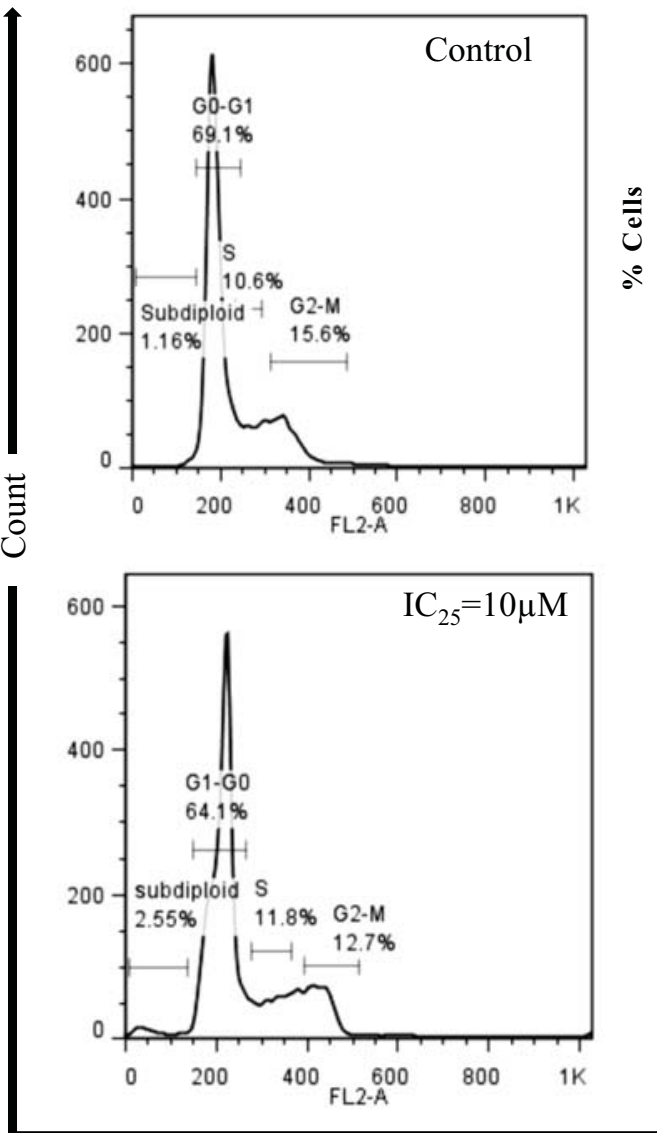

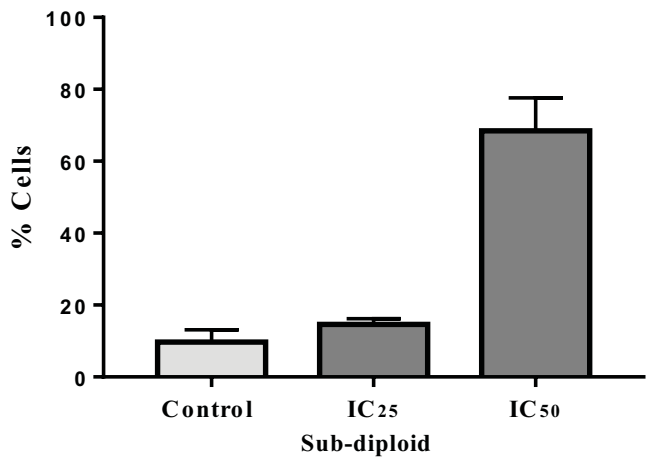

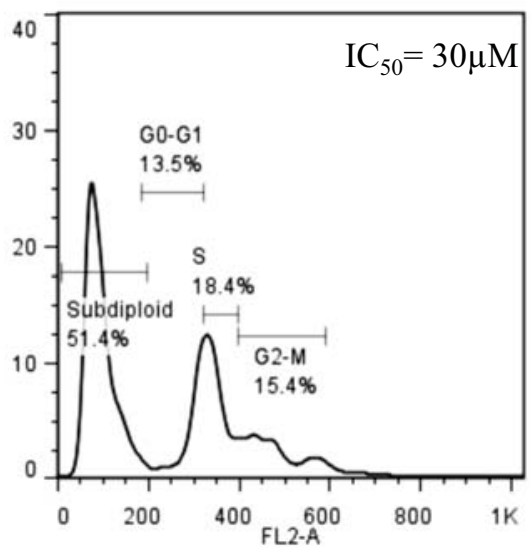

FL2-A
B

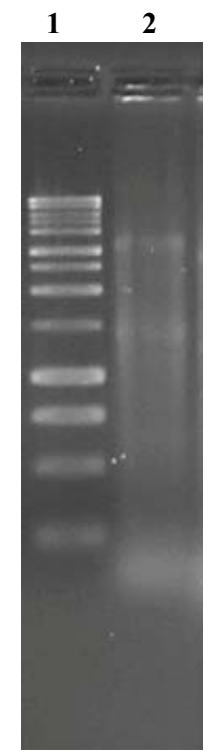

Fig. 1 The increase of subdiploid DNA content in U-87 MG cells treated with LyeTx I-b is not associated with DNA fragmentation. Illustrative histograms showing cell cycle changes $24 \mathrm{~h}$ after exposure to LyeTx I-b at $\mathrm{IC}_{25}$ and $\mathrm{IC}_{50}$ concentrations (10 and $30 \mu \mathrm{M}$, respectively). Statistical analysis of independent triplicate experiments showed significant differences between the negative control and the

by $\mathrm{LDH}$ release. The increase in extracellular LDH levels indicate cell membrane damage, and a reduction in cell viability was observed after $15 \mathrm{~min}$, upon labeling with calceinAM and Hoechst, as shown in Fig. 3B. In control cultures, viable cells were labeled with both green calcein-AM and blue Hoechst after treatment with the peptide, the number of cells displaying green fluorescence decreased, while the number of blue nuclei became evident upon staining with Hoechst. Therefore, LyeTx I-b peptide induces damage in cell membrane integrity and concomitantly reduces the viability of U-87 MG cells in a time-dependent manner.

The morphological alterations were identified by light microscopy after stain with trypan blue (Fig. 4A). Phase contrast microscopy confirmed the time-dependent morphological alterations observed with Calcein-AM and Hoechst labeling. Representative images of time-lapse analysis (Fig. 4B) are corroborate with our previous findings, and show morphological alterations, including changes in cell treated cells in terms of the subG1 (sub-diploid) population. B Analysis of U-87 MG cells genomic DNA treated with $30 \mu \mathrm{M}$ LyeTx I-b. Lane 1: DNA marker; Lane 2: U-87 MG DNA. Note, no DNA fragmentation ladder laddering formation was obviously viewed on ethidium bromide-stained gels (2\%) and photographed by UV illumination. Data shown are representative of three independent experiments

shape, and reduction in cell size, probably due to depletion of intracellular constituents after plasma membrane damage (Fig. 4B, arrows). The loss of membrane integrity was confirmed by scanning microscopy studies (Fig. 5). Electron micrographs of control, untreated U-87 MG cells exhibited plasma membranes with a continuous, smooth, morphology, while cells exposed to $30 \mu \mathrm{M}$ LyeTx I-b for 30,60 , and 180 min exhibited significant alterations in the cell membrane (Fig. 5), including numerous cell membrane pores, holes, and slits. These observations demonstrate that LyeTx I-b peptide is able to disrupt the plasma membrane, and suggests that necrotic cell death is the mechanism involved in the toxicity of peptide against U-87 MG cells. 


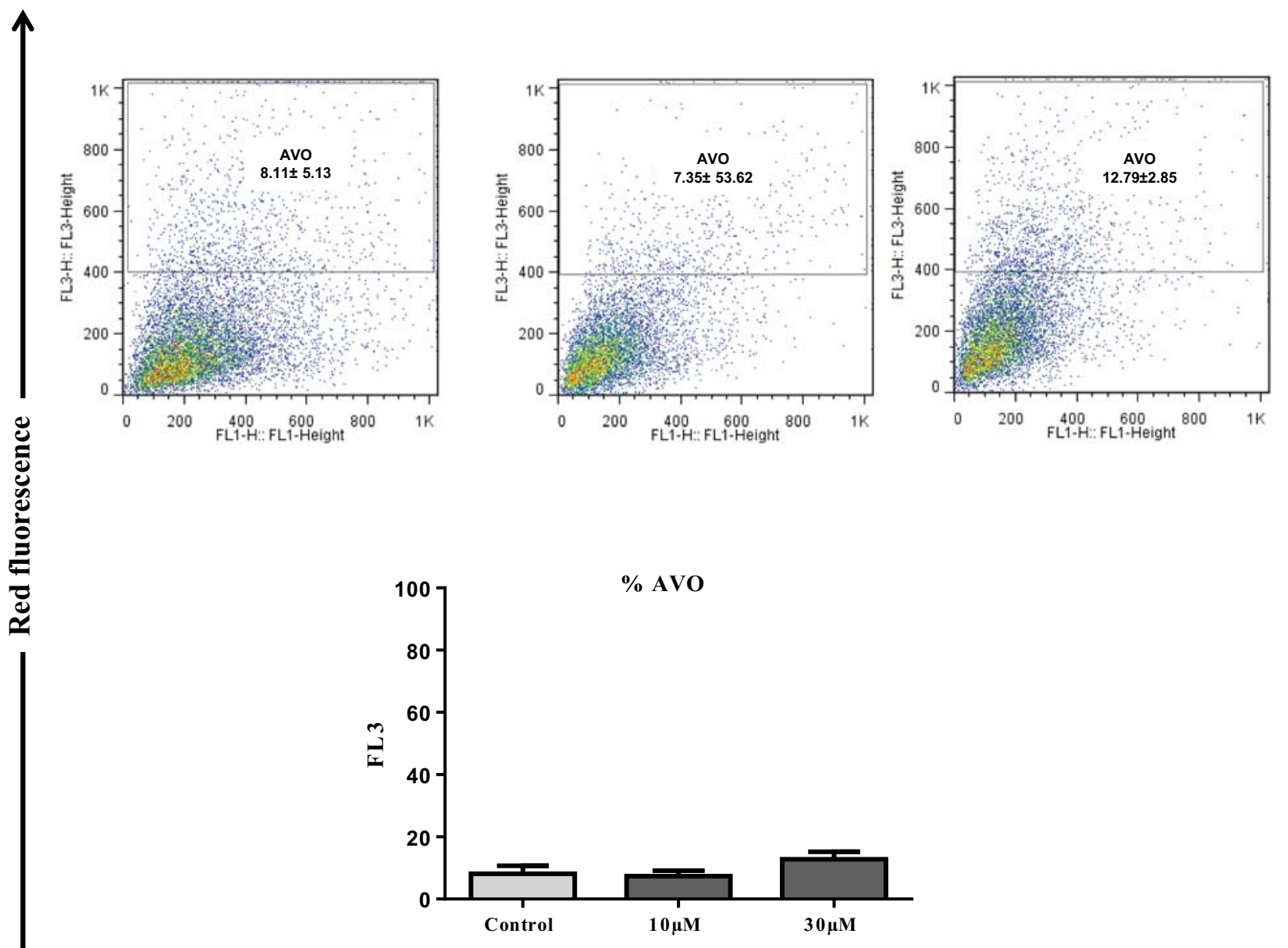

Green fluorescence

Fig. 2 Representative images showing flow cytometric measurement of U-87 MG cells after exposed to LyeTx-I_b peptide for $24 \mathrm{~h}$ and labeled with acridine orange. FL1-H indicates green color intensity,

\section{Electron microscopy studies displayed necrosis and regulated necrosis (necroptosis) as possible cell death processes involved with the LyeTx I-b peptide toxicity against U-87 MG cells}

To confirm that necrosis is induced by LyeTx I-b, a detailed ultrastructure study of cryofixed U-87 MG cells was carried out using transmission electron microscopy. Morphological structure alterations, indicating various cell death processes, were evaluated after 30, 60, and $180 \mathrm{~min}$ of $30 \mu \mathrm{M}$ peptide treatment. Transmission electron micrographs consistently displayed ultrastructure features that indicating a regulated necrosis process such as necroptosis as the principal findings in most of the observed fields. These characteristics include nuclei with mild DNA condensation, an increased cell volume with an electron-lucent nucleus and cytoplasm, and organelle vacuolization, but while FL3-H shows red color intensity (autophagy cells, AVO). Three independent experiments performed in duplicate (color figure online)

without rupture of nuclear or cell membranes (Fig. 6C). In addition, a progression of the necroptotic process was clearly observed after 30 min of treatment, no plasmatic membrane alterations could be observed in the early stage (Fig. 6C), and progressive enlargement of membrane pores could be observed from the intermediate late stages (Fig. 6D, E). These findings suggest that the aggressive action of LyeTx I-b at $30 \mu \mathrm{M}$ concentration precludes these cells from undergoing a regulated apoptotic cell death process. Moreover, ultrastructural studies showed no morphological alterations indicating autophagy such as presence of autophagosomes with intracellular organelles and disappearance of some cytoplasmic organelles, corroborating with the flow cytometry analysis (Fig. 1).

Considering these data, the percentages of cells undergoing necroptosis, necrosis, and apoptosis after treatment with LyeTx I-b were determined using high-resolution light 


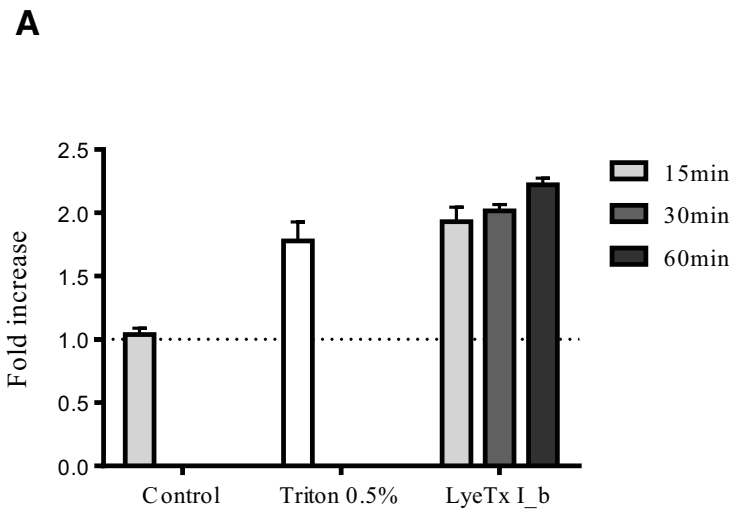

Fig. 3 Effect of LyeTx I-b on LDH release and on the morphology of U-87 MG cells. A U-87 MG cells were treated with peptide $(30 \mu \mathrm{M})$ for 15,30 and $60 \mathrm{~min}$ and LDH levels were evaluated $(n=3)$. Triton $\mathrm{X}-100(0.1 \%)$, a nonionic surfactant, was used as a positive control of cell membrane disruption. Relative LDH concentration was calculated as a $\%$ of the positive control. B U-87 MG cells were treated
B

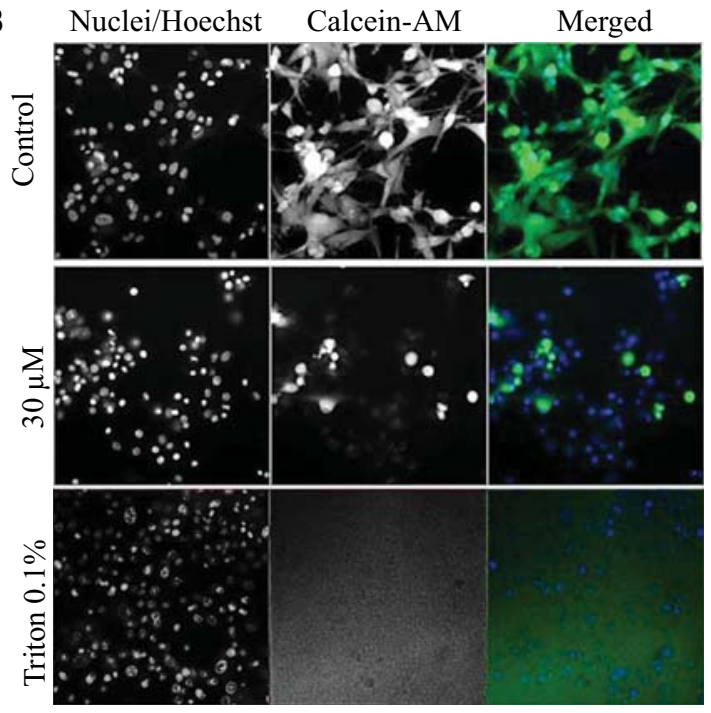

with peptide $(30 \mu \mathrm{M})$ for $15 \mathrm{~min}$ and then labeled with Calcein-AM and Hoeschst 3342. Double positive cells (green and blue) were counted as viable. The number of viable cells per field was detected using a high-content screening microscope (Scale bar, $50 \mu \mathrm{m}$ ). At least 3 independent experiments were performed (color figure online)

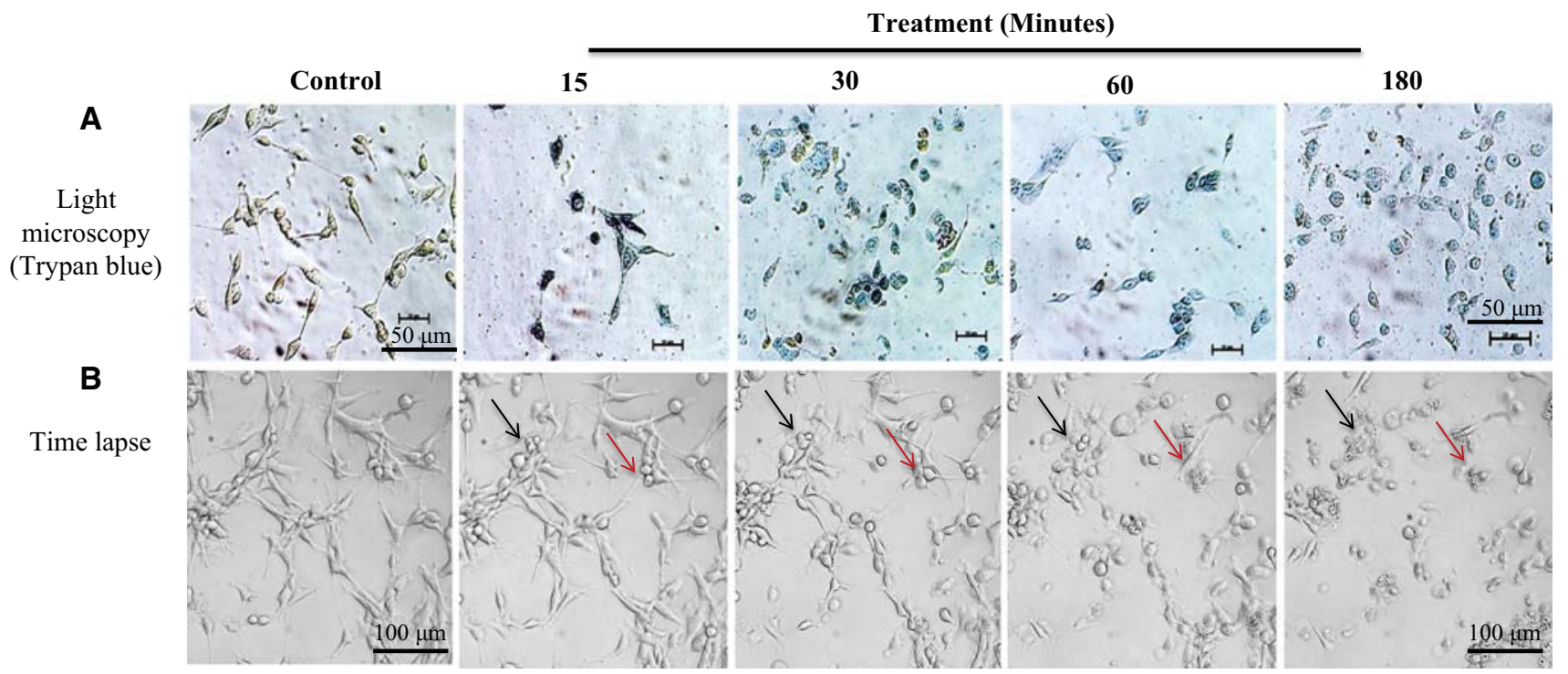

Fig. 4 Partial disintegration of U-87 MG cell membranes after exposure to $30 \mu \mathrm{M}$ LyeTx I-b. Control or treated cells were treated with the peptide for $0,15,30,60$, and $180 \mathrm{~min}$, stained with trypan blue (A) and during time-lapse analysis (B). Red and black arrows repre-

microscopy (HRLM) morphometric analysis. The results confirmed necroptosis as the main cell death process, while necrosis was measured as a minor proportion. The percentage of cells under apoptosis was similar to the control cells, as shown in Table 2. Apoptosis was identified by the chromatin condensation levels followed by nuclear and sent alterations in both cells. Scale bars: $(\mathbf{A})=50 \mu \mathrm{m} ;(\mathbf{B})=100 \mu \mathrm{m}$. Three independent experiments were done in duplicate for trypan blue, and time-lapse two experiments performed in triplicates (color figure online)

organelles shrinkage and the formation of apoptotic bodies (supplementary Fig. 1A). Necrosis was best characterized by the huge plasma membrane rupture with extravasation of intracellular contents and organelles to the extracellular medium (supplementary Fig. 1B). 


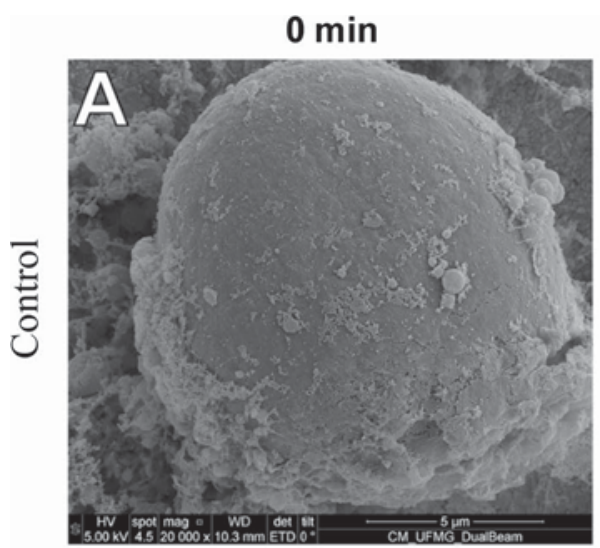

$30 \mathrm{~min}$

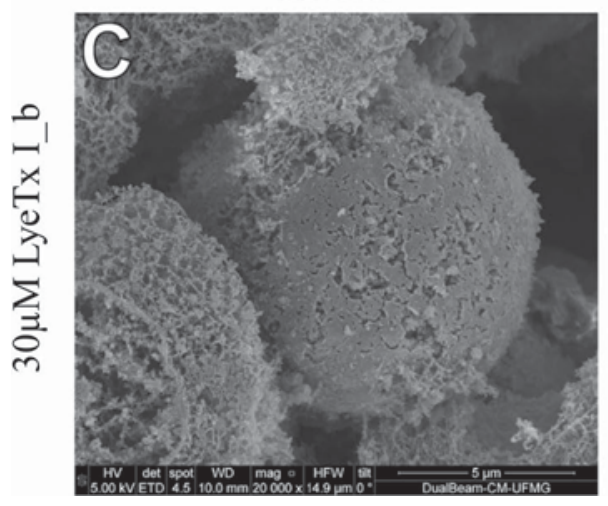

$180 \mathrm{~min}$

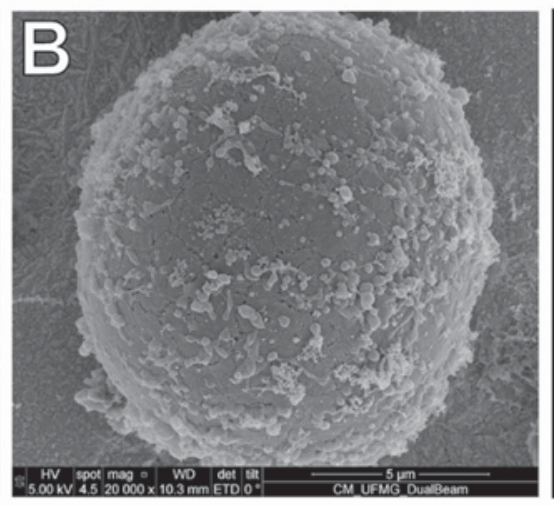

$60 \mathrm{~min}$

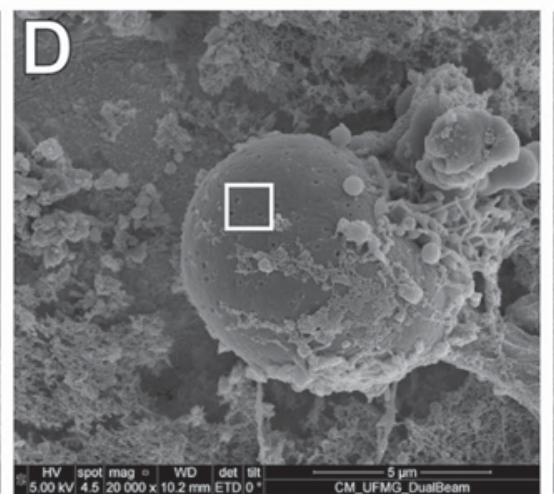

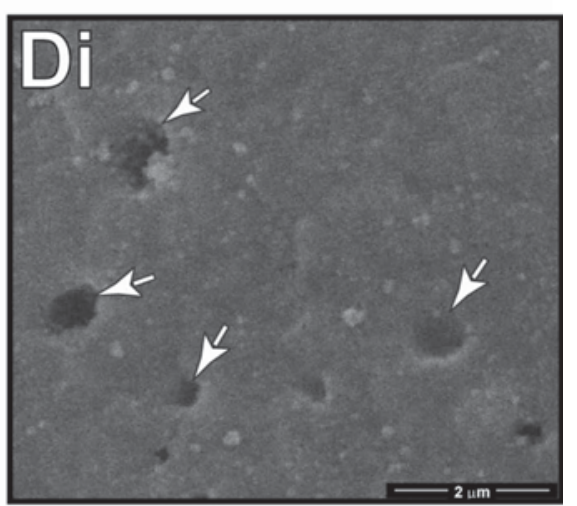

$180 \mathrm{~min}$

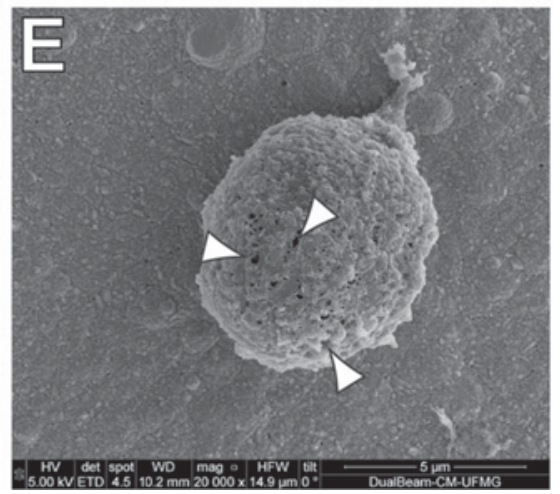

Fig. 5 Ultrastructural changes on the U-87 MG cell surface exposed to $30 \mu \mathrm{M}$ LyeTx I-b. A, B Control cells at $0 \mathrm{~min}$ and after $180 \mathrm{~min}$ of incubation, respectively, displaying a smooth and homogeneous surface, with few membrane disruptions. C, D, Di and $\mathbf{E}$ After 30, 60, and 180 min of treatment with LyeTx I-b slits (C), pores (arrows) (Di) and hole (arrowheads) were detected in the plasma membrane. Di is a higher magnification view of the white-boxed area in D. U-87

\section{Pre-treatment with necrostatin-1 reduces loss of viability induced by the peptide on U-87 MG cells}

To further confirm that necroptosis was involved in the cytotoxicity of the peptide against U-87 MG cells, assays with necrostatin-1, a specific inhibitor of necroptosis, were performed. Triton X 100 was used as a positive control. Pretreatment of U87 cells with necrostatin-1 partially protected the cells from the toxicity of the peptide at $12.5,25$, and $50 \mu \mathrm{M}$, as observed by the higher values of resorufin fluorescence intensity, compared to the same treatment without necrostatin-1 (Fig. 7).

\section{LyeTx I-b peptide induction of necroptosis confirmed by imaging stream flow cytometry}

Experiments using flow cytometric analyses were performed to differentiate between apoptosis, late apoptosis, and necroptosis after treatment of U-87 MG with the
MG cells were cultured, fixed using high-pressure freezing (HPF), freeze-substituted and then processed for scanning electron microscopy (SEM). A total of 165 electron micrographs was randomly taken and analyzed at magnifications ranging from 10,000 to $\times 20,000$. Bars: $\mathbf{A}-\mathbf{E}=5 \mu \mathrm{m} ; \mathbf{D i}=2 \mu \mathrm{m}$. Three independent experiments were performed, $N=3$

peptide. Microscopy was combined with flow cytometry in one measurement to analyze morphological and biochemical features of cell death in a quantitative way, using classical Annexin V/PI iodine staining to identify cells with phospholipids exposure and loss of membrane integrity. This strategy allowed classification of cells only labeled with Annexin $\mathrm{V}$ in early apoptosis, double positive cells (Annexin V and PI) in late apoptosis or necroptosis, and cells labeled only with PI in necrotic cells. To evaluate necroptotic cells, an image-based analysis was used to measure nuclear morphology, distinguishing cells with secondary necrosis due to late apoptosis and necroptosis, simultaneously (Pietkiewicz et al. 2015). The results demonstrated that LyeTx I-b induced necroptotic death in U-87 MG cells after a $3 \mathrm{~h}$ treatment, observed by double positive staining with Annexin V and PI, differently than observed in control cells. Control cells maintained a round shape and staining for either Annexin V or PI could not be detected (Fig. 8A). Moreover, the number of double positive cells increased in correlation with increasing 


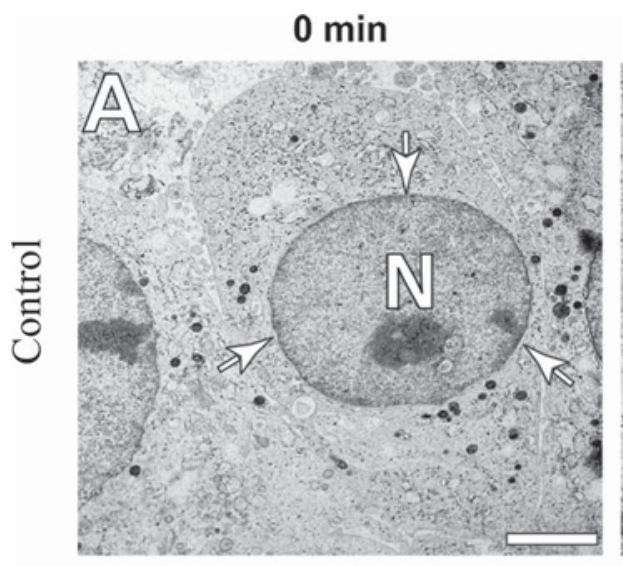

$30 \mathrm{~min}$

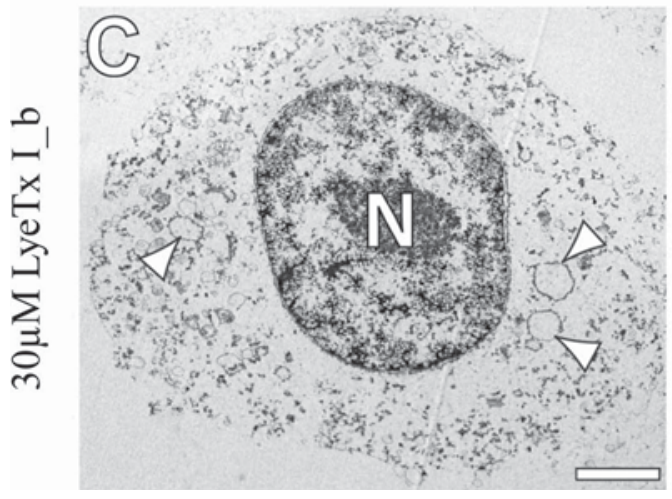

$180 \mathrm{~min}$

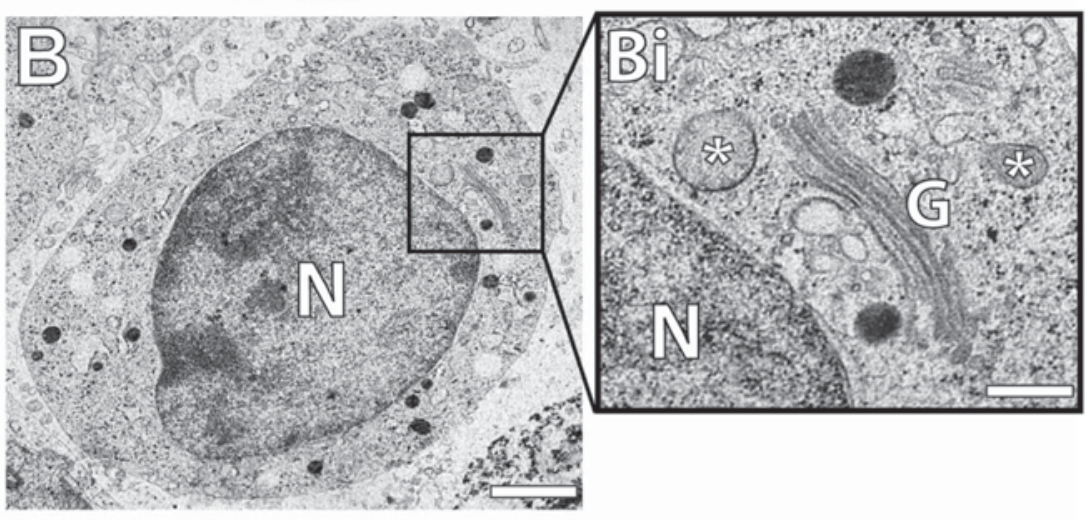

$60 \mathrm{~min}$

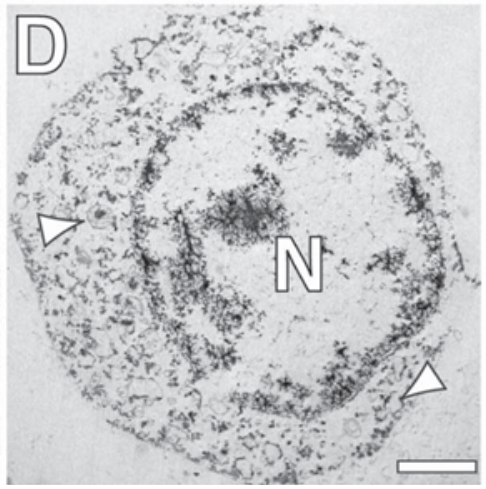

$180 \min$

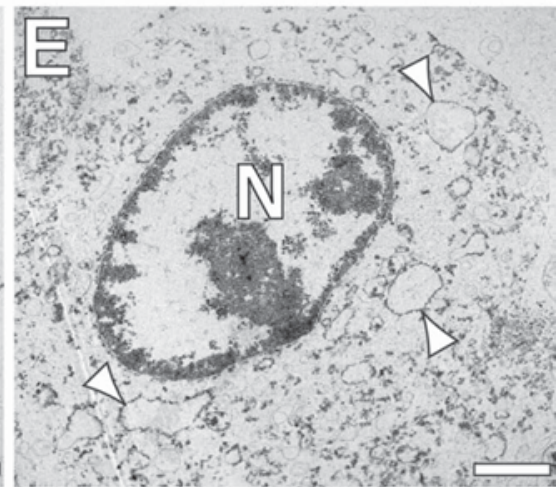

Fig. 6 Intracellular ultrastructure of U-87 MG cells treated with $30 \mu \mathrm{M}$ LyeTx I-b. A, B Control cells showing ultrastructural characteristics indicative of cellular activation such as the presence of a well round and central euchromatic nucleus $(\mathrm{N})$ with fine distinction from the nuclear envelope (arrows). A higher magnification in (Bi) shows a prominent Golgi apparatus $(\mathrm{G})$ and mitochondria (asterisk). C-E Cells after 30 min of treatment, in different stages (early, intermediate, and late) of the necroptosis process, identified by the increase in the cell volume, swelling of the nucleus and cytoplasmic organelles (arrowheads), and electron-lucent nucleus and cytoplasm.
Differences in plasma membrane alterations ranging from membrane integrity maintenance (early stage) to the progressive membrane ruptures (middle-to-late stages) were detected. Human glioblastoma cells were cultivated and processed for transmission electron microscopy using high-pressure freezing and freeze substitution. A total of 80 electron micrographs showing the entire cell profile and nucleus was randomly taken and analyzed at magnifications ranging from $\times 4200$ to $\times 26,500$. Bars: $\mathbf{A}-\mathbf{E}=2 \mu \mathrm{m} ; \mathbf{B i}=500 \mathrm{~nm}$. The micrographs shown here are representative of three experiments performed in triplicate peptide concentration and time of incubation, as observed in Fig. 8B. After $3 \mathrm{~h}$ of treatment with $30 \mu \mathrm{M}$ LyeTx I-b, the percentage of double positive cells was $59.09 \%$, while after 6 h, it was $80.9 \%$ (Fig. 8 C).

Table 2 Morphometric analysis of transmission electron micrograph (TEM) of U-87 MG cell line after exposure to $30 \mu \mathrm{M}$ LyeTx I-b for 30,60 , and $180 \mathrm{~min}$

\begin{tabular}{lclcc}
\hline$\%$ & Normal & Apoptosis & Necroptosis & Necrosis \\
\hline Control & 89.7 & 2.6 & 3.9 & 3.9 \\
30 min & 24.4 & 6.5 & 53.6 & 15.5 \\
$1 \mathrm{~h}$ & 5.7 & 1.9 & 64.2 & 28.3 \\
$3 \mathrm{~h}$ & 4.7 & 1.7 & 63.3 & 30.3 \\
\hline
\end{tabular}

The total count was at least 300 cells for each group

\section{Discussion}

Cationic antimicrobial peptides (AMPs) are antimicrobial peptides that are able to stimulate innate immunity to fight against infections and have dual activities as anticancer and antimicrobial agent (Felício et al. 2017; Pane et al. 2017). The presence of unsaturated lipid chains in cancer cell membranes confers negative charges that allow them bind with the positive charges present in cationic peptides, increasing the selectivity of these peptides for cancer cells (Chen et al. 2014; Deslouches and Di 2017). Furthermore, anticancer cationic peptides have many features such as mild toxicity without accumulation in different tissues and eventually selectivity and specificity for cancer targets and receptors (Perez-Pitarch et al. 2017). In this work, we focused on brain cancer cells, specifically in one representative lineage 
Fig. 7 Effect of LyeTx I-b in cell membrane integrity and viability in the presence of necrostatin-1, a specific inhibitor of necroptosis. U-87 MG cells were pre-treated or not with $100 \mu \mathrm{M}$ necrostatin-1 (nec1) for $1 \mathrm{~h}$, followed by incubation with various concentrations of the peptide or Triton $\times 100$. Cell viability was measured by resazurin assay. The data shown here are representative of two experiments performed in triplicate. $* * * P<0.01$, one-way ANOVA followed by Tukey multiple comparison test

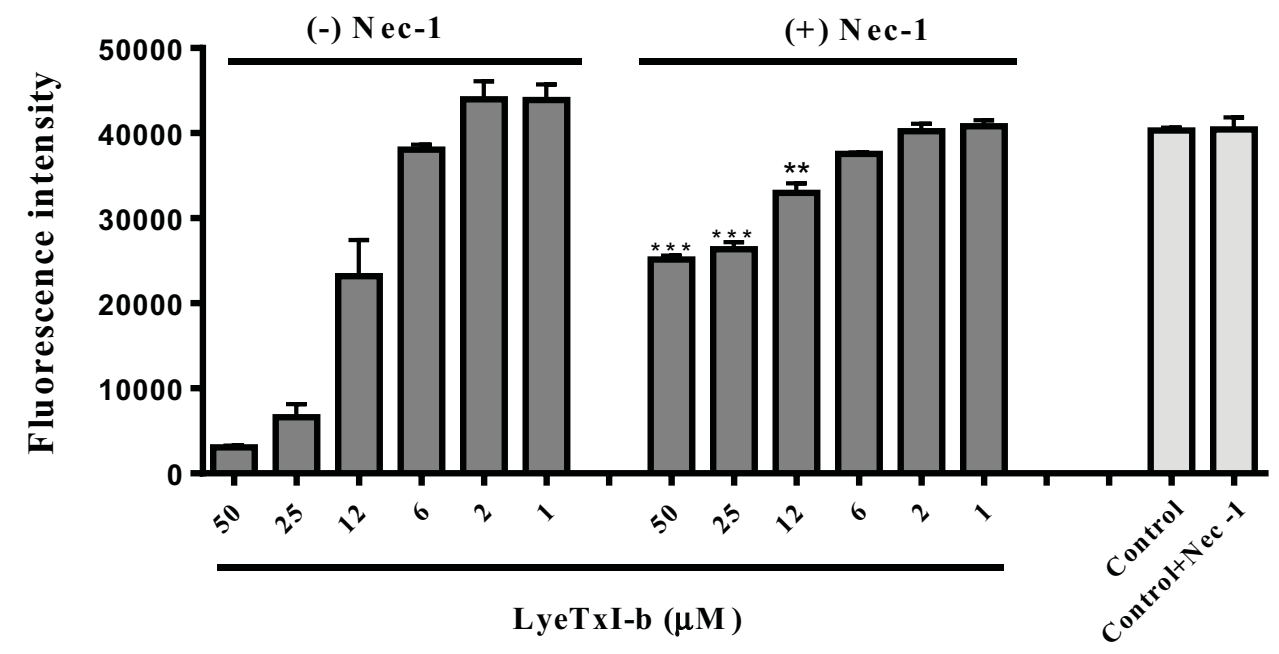

of glioblastoma multiform, U-87 MG cells as a model to understand the cytotoxic mechanism of LyeTx I-b peptide and evaluate it anticancer potential. This peptide displayed excellent antimicrobial activities in vitro and in vivo (Reis et al. 2018). The aggressive nature of this class of tumor and the poor prognosis of patients with GBM underscore the clear requirement for more precise and powerful treatments (Marqus et al. 2017).

In the early phase of drug discovery, the predictive assays based on cells are essential to characterize the activity of the new compound in a specific model of disease. Most of the authors in the literature claim that the potential antitumor activity of AMPs is due to a selective recognition of cancer cells via electrostatic interactions (Chen et al. 2014; Deslouches and Di 2017). To characterize the cytotoxicity of LyeTx I-b peptide and it anticancer potential, we used as a predictive models tumor cells derived from non-tumoral cells (human PBMC, human fibroblast, monkey kidney cells) and to measure the general toxicity hazard.

We found that LyeTx I-b peptide effectively inhibits the growth of some cells derived of brain cancers in a dosedependent manner (Table 1), whereas neuroblastoma cells (SHSY5Y, IC $_{50}=93 \mu \mathrm{M}$ ) were less susceptible, comparing with glioma cells $\left(\mathrm{IC}_{50}=29\right.$ and $20 \mu \mathrm{M}$, respectively, to U-87 MG and U373-MG). When evaluated against representative models of non-tumoral cells, the peptide showed more cytotoxicity against human $\mathrm{PBMC}$, a representative model of immunotoxicity $\left(\mathrm{IC}_{50}=4 \mu \mathrm{M}\right)$, comparing with human fibroblast GM-637 cells and monkey kidney cells Vero (IC50>100 $\mu \mathrm{M}$ ). Most of the chemotherapeutic agents in clinics also induce adverse effects such as myelosuppression, cardiotoxicity, ototoxicity, neurotoxicity, and malignancies (Swartz et al. 2015). Treatment with anticancer drugs such as cisplatin, etoposide, and paclitaxel is frequently accompanied by toxic side effects including immunosuppression (Kim et al. 2016; Galluzzi et al. 2015;
Lee and Jeon 2001). To Galluzzi et al. such "side" effects are desirable to suppress immunosuppressive circuitries induced by tumors. Hemolytic effect is a common finding observed to AMPs. We observed that peptide-induced hemolysis on human erythrocytes (30-35\%), indicating disruption of RBC membrane, similar to the hemolytic effects of others alphahelix peptides as described by Huang et al. (2011). These effects are corroborated by the findings of Bacalum and Radu (2015) evaluating the therapeutic index of 11 MPAs (alpha-helix, beta, or random coil). They used hemolysis and PBMC viability as parameters as more realistic to identify side effects. Some AMPs like Melittin displayed cytotoxicity at lower micromolar range $(<10 \mu \mathrm{M})$ for both PBMC and hemolytic activity. Another peptides like Dermaseptin 1 and Indolicidin showed cytotoxicity against $\mathrm{hRBc}$ and PBMC in similar concentration (ranging from 10 to $50 \mu \mathrm{M}$ ). Hydrophobicity is a key factor of AMPs cytotoxic efficacy against cancer cells and less hemolytic activity because of the presence of alanine residue in $\alpha$-helical peptides that might help to penetrate and accumulate in cancer cell membrane, leading to disrupt cell membrane rapidly than red blood cells. In addition, V13K, K4R2-Nal2-S1, and D-K6L9 are cationic peptides, which have been demonstrated high specificity to kill various cancer cells with hemolytic effect, similar to our results (Chu et al. 2015; Huang et al. 2011).

To elucidate the mechanism of cell death involved in the cytotoxic activity of LyeTx I-b against U-87 MG, classical cell death mechanisms such as apoptosis, necrosis, and autophagy were investigated using flow cytometry and morphological studies. To evaluate apoptosis, cell-cycle analyses demonstrated an increase in the content of subdiploid DNA in U-87 MG cells after treatment with $30 \mu \mathrm{M}$ peptide (Fig. 1). Although this result indicates DNA fragmentation, agarose gel analyses clearly showed that the treatment of U-87 MG cells with the peptide did not induce apoptotic pattern of apoptosis, since no ladder was observed (Fig. 1). 


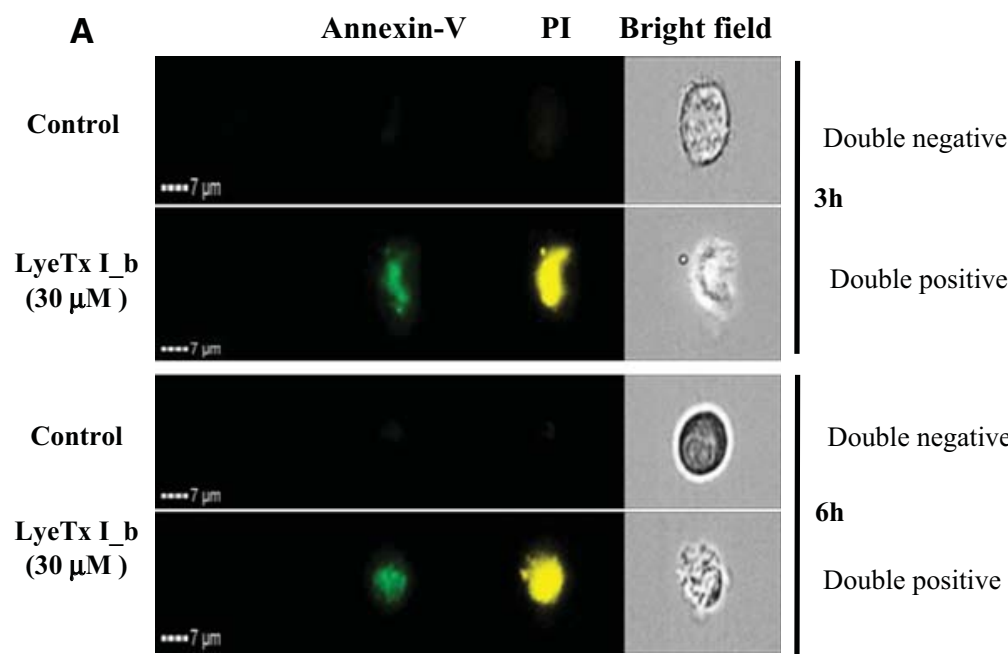

C
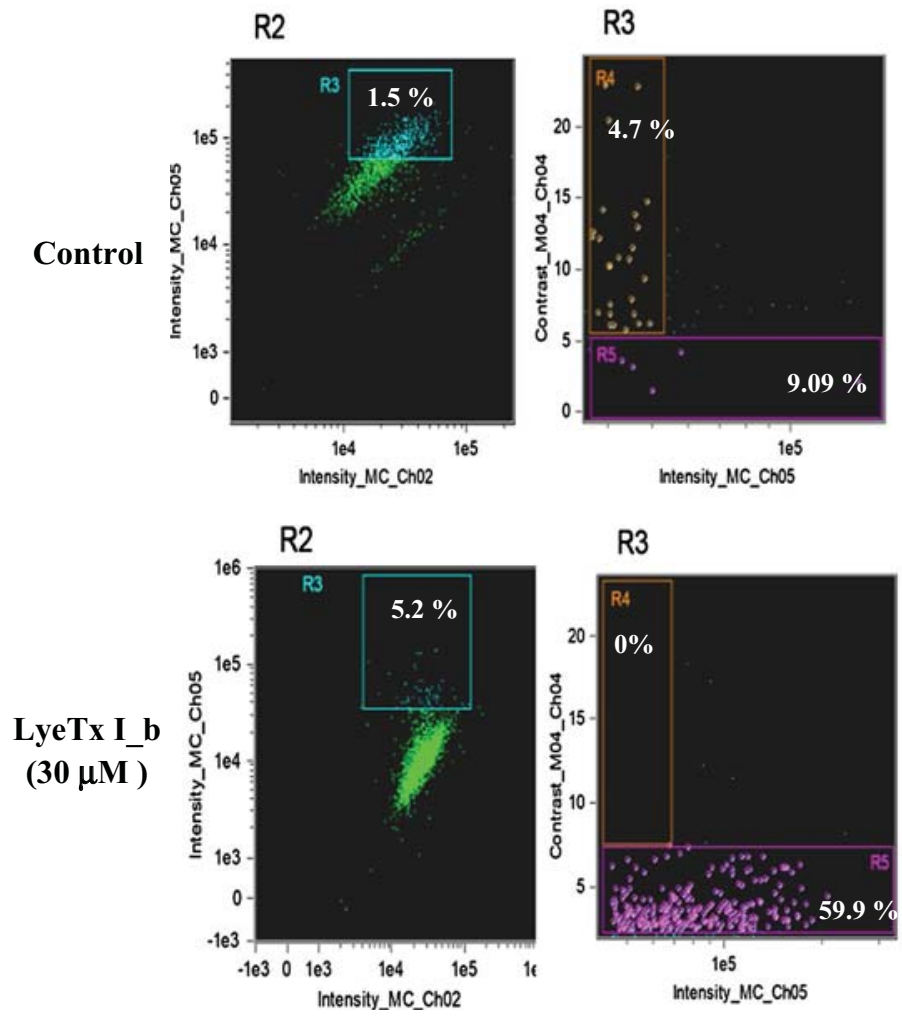

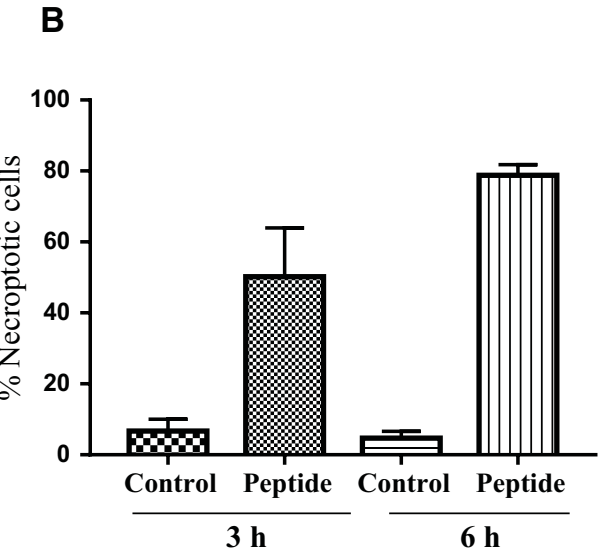

6h
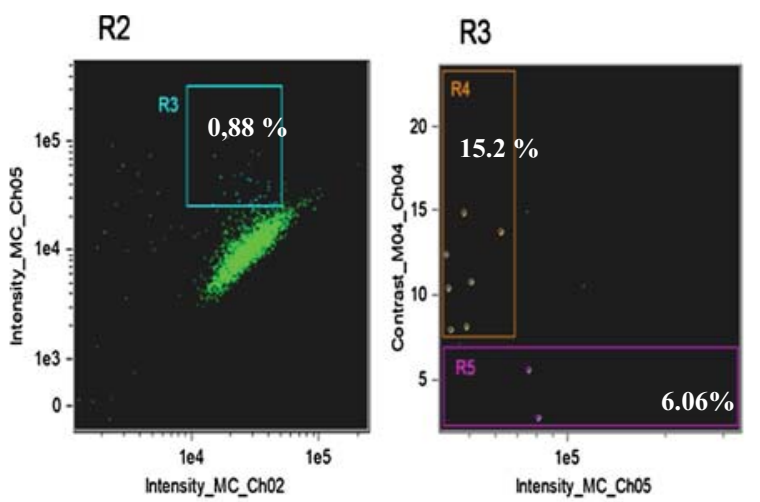

R2

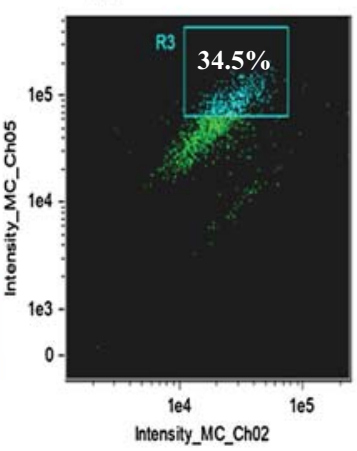

R3

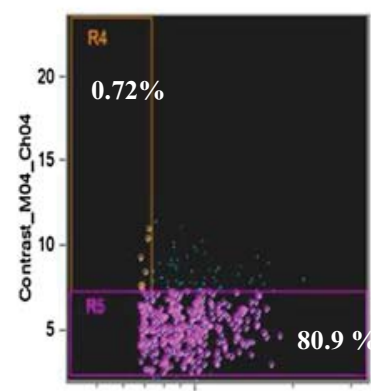

105
Fig. 8 Imaging stream flow cytometry of U-87 MG cells treated or not with LyeTx I-b.U-87 MG cells were treated with $30 \mu \mathrm{M}$ peptide for 3 and $6 \mathrm{~h}$ and labeled with Annexin V (An) and propidium iodide (PI) and classified as live (double negative), early apoptotic (An positive), late apoptotic (double positive) or necroptotic (double positive). Dots were constructed displaying intensity of Annexin, $\mathrm{MC}-\mathrm{Ch} 02$; aspect ratio of PI stained nucleus, intensity of MC-Ch-05 and con-

The cells undergoing apoptotic cell death exhibit different morphological and biochemical alterations such as DNA fragmentation due to endonucleases enzymes like caspase-3 that cleave the chromatin into fragments with $180 \mathrm{bp}$ that trast morphology of PI, contrast MC_Ch04. A Representative images of U-87 MG, treated or not, acquired simultaneously with double negative and positive labeling (An+/PI+), as well as in bright field. B Percentage of necroptotic cells treated with $30 \mu \mathrm{M}$ LyeTx I-b for 3 and $6 \mathrm{~h}$ in two independent experiments. Graphs represent a different quantitative parameter that distinguishes between necroptosis and apoptosis

appear after running the DNA in agarose gel, similar to a "ladder" (Matassov et al. 2004). These results were also supported by FACS analyses of one early apoptotic phenomena such as phosphatidylserine exposure since less than $15 \%$ 
of apoptotic cells, and were detected in different times of incubation of U-87 MG cells with the peptide (Table 2 and Fig. 6, respectively).

Furthermore, autophagy, another cell death correlated with chemoresistance, recurrence, and metastasis does not seem to be involved (Ojha et al. 2015). Under ultrastructural studies, this type of cell death usually demonstrates sequestration of cytoplasmic components within a doublemembrane structure called the autophagosome, followed by delivery to lysosomes for degradation. These lysosomes can be detected with acridine orange that can be quantified by flow cytometry (Gewirtz 2014). There was no indication of cells in autophagic process, since the presence of AVO was lower than $15 \%$, comparing with the control. Even considering that other markers of autophagy have not been investigated here, such as microtubule-associated protein LC3, which plays a key role for the formation of autophagosomes (Eum and Lee 2011; Brauchle et al. 2014). Morphological analysis using MET (Fig. 6) clearly demonstrated no signs of autophagy alterations such as the presence of doublemembrane structure with undigested cytoplasmic organelles including mitochondria or endoplasmic reticulum as described by Mizushima et al. (2010). These results demonstrated that neither apoptosis nor autophagy were the main mechanisms triggered by the peptide on U-87 MG cells.

Most of the data presented here indicated that LyeTx I-b induced necrosis or a programmed necrosis through rapid cell membrane damage. Trypan blue uptake in U-87 MG cells occurred after 15 min incubation with $30 \mu \mathrm{M}$ LyeTx I-b (Fig. 3A), as well as, time-lapse studies (Fig. 4B) showed cell membrane disruption. This effect was in a concentration dependent, confirmed by measurement of LDH release and calcein-AM. Comparable data were observed by Burns et al. who described the effect of pHLIP-KLAKLAK c antimicrobial peptide on the integrity of MDA-MB-231 cell membrane (Burns et al. 2016). They also showed trypan blue uptake after treating with the toxic peptide, disruption, and permeabilization of the cell membrane as a result of pore formation (Tran et al. 2011).

Disruption of U-87 MG membrane after treatment with the peptide was confirmed herein by scanning microscopy studies. Our data suggest that LyeTx I-b was able to cause damage to the cell membrane after $30 \mathrm{~min}$ of treatment, forming "holes" after $180 \mathrm{~min}$, leading to membrane destruction, as shown in Fig. 5. These findings suggested that LyeTx I-b can induce pores formation in the membrane of U-87 MG cells, in a time- and dose-dependent way, leading to plasma membrane permeabilization and consequent cell degeneration. Scanning microscopy analyses of U-87 MG cells after treatment with the cationic anticancer peptide bacteriocin LS10 demonstrated cell membrane disintegration, similar to our findings (Baindara et al. 2017). LyeTx I-b almost perfect helical structure, as observed from NMR data, also suggests that this peptide is prone to act as a membranolytic peptide (Reis et al. 2018). Currently, in vitro studies of LyeTx I-b using large unilamellar vesicles (LUVs) measured by biophysical techniques such as isothermal titration calorimetry (ITC), aiming to better explain the nature of such interactions, are being carried out by our group (to be published elsewhere). Lytic activities of peptides isolated from other venoms have been described. $\mathrm{ABH} 3$ peptide is a BCL-2 homologue artificial lytic peptide, which exhibits the ability to rapidly disrupt the cell membrane in different cancer cell lines HCT116, HeLa, U937, MCF-7, and MDAMB-231 (Liu et al. 2016). A similar study, antimicrobial peptide temporin-1CEa, extracted from skin secretions of the Chinese brown frog demonstrated that temporin-1CEa able to disrupt cancer cell membranes, causing loss of membrane integrity due to the formation of transmembrane pores that allow an uptake of the peptide into the cytoplasmic compartment of the cancer cell (Wang et al. 2013). However, we did not evaluate how the pores and were formed and their size in U-87 MG cells after treatment with the peptide in this approach.

Interesting finding observed after transmission electronic microscopy (TEM) and ultrastructural analysis suggested that the peptide at $30 \mu \mathrm{M}$ induced a regulated type of necrotic cell death in U-87 MG. Necrotic cells at the light of TEM studies have unique morphological features, such as swollen organelles, nuclear membrane dilatation, little chromatin condensation and breakdown of the plasma membrane due to oncosis, increasing the volume of cell membranes (Vandenabeele et al. 2010). Necroptosis or regulated necrosis were frequently identified in most of the fields, characterized by swollen nuclei, vacuolization, increase of cell volume, and integrity of cell membrane (Fig. 6), in agreement with previously morphological alterations described this cell death process, like swollen nucleus, increased cell volume and mild chromatin condensation (Su et al. 2016). We not only found cells with a necroptotic profile but also few cells in necrosis and apoptosis (nuclei with condensed chromatin and reduction of cell volume), at lower frequencies. Morphometric analyses (Table 2) demonstrated that after $30 \mathrm{~min}$, more than $50 \%$ of the cells were necroptotic, less than $20 \%$ were necrotic and less than $3 \%$ were apoptotic. These findings were time dependent. TEM analysis characterizes that necroptotic cell death has been described in the literature (Sun et al. 2016). Our data demonstrated morphological necroptosis signs in U-87 MG cells after treating with $30 \mu \mathrm{M}$ LyeTx I-b, characterized by the swelling of nucleus and mitochondria, increase in cytoplasm volume, membrane disruption, cytoplasm vacuoles, and release of cellular content. Other studies using TEM showed necroptosis signs after treatment with natural alkaloid compounds (martine) in cholangiocarcinoma cells (CCA) characterized by cytoplasmic vacuolation and extensive swelling of 
organelle and loss of plasma membrane integrity (Xu et al. 2017). As a consequence of cellular swelling and rupture of the plasma membrane, they also observed an extravasation of cellular components and increase in LDH, as observed in the present study (Zhao et al. 2016).

To better characterize the necroptotic death triggered by LyeTx I-b on U-87 MG, cells were pre-treated the cells with necrostatin-1 (Nec-1), which is a specific inhibitor of necroptosis in human glioma cells (Melo-Lima et al. 2014; Cho et al. 2011). As observed in Fig. 7, pre-treatment of U-87 MG cells with Nec-1 protected U-87 MG cells against the cytotoxicity induced by the peptide, observed by an increase in the number of viable cells, comparing with control. Flow cytometric studies (Fig. 8) corroborate with these data, showing an increase in the number of necroptotic cells after $3 \mathrm{~h}$ treatment, in a time- and dose-dependent manner, $59.9 \%$ of cells were necroptotic, and after $6 \mathrm{~h}$, this number increasing to $80.9 \%$,. These data were in agreement with those observed after the morphometric analysis by TEM (Table 2). Although other direct molecular markers of necroptosis (TNF-alpha receptor activation; MLKL phosphorylation, RIP3 involvement) have not been evaluated in this study, the use of the specific necroptosis inhibitor necrostatin, flow cytometry assays, and ultrastructural studies clearly demonstrate that necroptosis is the main type of cell death induced by the peptide.

\section{Conclusion}

In the present study, we reported that the cationic antimicrobial peptide LyeTx I-b presents cytotoxicity against brain cancers cells. This effect involves induction of necroptosis in glioblastoma cells as the main cell death process. In addition, the peptide showed undesirable cytotoxicity such as hemolytic effect and immunotoxicity, but this was similar to other anticancer drugs used in clinic. Therefore, this deleterious effect cannot be considered as a restrictive reason to invalidate the antitumor potential of this peptide. We suggested that the novel synthetic LyeTx I-b peptide is an interesting prototype to be used as a model to develop new chemotherapeutics.

Acknowledgements Some of the light and fluorescence microscopy data shown in this work were obtained at Centro de Aquisição e Processamento de Imagens (CAPI-ICB/UFMG; http://www.icb.ufmg.br/ capi/). Experiments and analyses involving electron microscopy were performed at the Center of Microscopy of UFMG (http://www.micro scopia.ufmg.br).

Funding This work was supported and financed by CNPq (Conselho Nacional de Desenvolvimento Científico e Tecnológico), FAPEMIG (Fundação de Amparo a Pesquisa do Estado de Minas Gerais), CAPES (Coordenação de Aperfeiçoamento de Pessoal de Nível Superior) in Brazil and the Alexander Von Humboldt Foundation/Germany (Process
99999.008121/2014-01). Abdel-Salam, M. A. L. and Elaine M. SouzaFagundes are recipients of CAPES fellowship, and Maria Elena de Lima Drug Discovery grant. On top, this work was supported by the Land BW (Germany), the Doerenkamp-Zbinden foundation, the DFG (RTG1331, KoRS-CB), the BMBF (NeuriTox) and the European Project EU-ToxRisk.

\section{Compliance with ethical standards}

Conflict of interest Authors declare no conflict of interest regarding the publication of this paper such as personal or professional relationships, affiliations, knowledge, or beliefs in the subject matter or materials discussed in this manuscript.

Ethical statement The collection of human blood samples was a part of the project approved by the UFMG Research Ethics Committee (COEP), under Protocol Number 666.658/2016, and all healthy donors provided written consent.

\section{References}

Aissaoui D, Mlayah-Bellalouna S, Jebali J et al (2018) Functional role of Kv1.1 and Kv1.3 channels in the neoplastic progression steps of three cancer cell lines, elucidated by scorpion peptides. Int J Biol Macromol 111:1146-1155. https://doi.org/10.1016/j. ijbiomac.2018.01.144

Aroui S, Dardevet L, Ben Ajmia W et al (2015) A novel platinummaurocalcine conjugate induces apoptosis of human glioblastoma cells by acting through the ROS-ERK/AKT-p53 pathway. Mol Pharm 12:4336-4348. https://doi.org/10.1021/acs.molph armaceut.5b00531

Bacalum M, Radu M (2015) Cationic antimicrobial peptides cytotoxicity on mammalian cells: an analysis using therapeutic index integrative concept. Int J Pep Res Therap 21:47-55. https://doi. org/10.1007/s10989-014-9430-z

Baindara P, Gautam A, Raghava GPS, Korpole S (2017) Anticancer properties of a defensin like class IId bacteriocin Laterosporulin10. Sci Rep 7:46541. https://doi.org/10.1038/srep46541

Brauchle E, Thude S, Brucker SY, Schenke-Layland K (2014) Cell death stages in single apoptotic and necrotic cells monitored by Raman microspectroscopy. Sci Rep 4:4698. https://doi. org/10.1038/srep04698

Bubien JK, Ji H-L, Gillespie GY et al (2004) Cation selectivity and inhibition of malignant glioma $\mathrm{Na}+$ channels by Psalmotoxin 1. Am J Physiol Cell Physiol 287:C1282-C1291. https://doi. org/10.1152/ajpcell.00077.2004

Burns KE, McCleerey TP, Thevenin D (2016) pH-selective cytotoxicity of pHLIP-antimicrobial peptide conjugates. Sci Rep 6:28465. https://doi.org/10.1038/srep28465

Chan FK-M, Moriwaki K, De Rosa MJ (2013) Detection of necrosis by release of lactate dehydrogenase activity. Methods Mol Biol (Clifton, NJ) 979:65-70. https://doi.org/10.1007/978-1-62703 $-290-2 \_7$

Chen C, Hu J, Zeng P et al (2014) Molecular mechanisms of anticancer action and cell selectivity of short alpha-helical peptides. Biomaterials 35:1552-1561. https://doi.org/10.1016/j.bioma terials.2013.10.082

Cho Y, McQuade T, Zhang H et al (2011) RIP1-dependent and independent effects of necrostatin-1 in necrosis and $\mathrm{T}$ cell activation. PLoS ONE 6:e23209. https://doi.org/10.1371/journ al.pone.0023209 
Chu H-L, Yip B-S, Chen K-H et al (2015) novel antimicrobial peptides with high anticancer activity and selectivity. PLoS ONE 10:e0126390. https://doi.org/10.1371/journal.pone.0126390

Cohen-Inbar O, Zaaroor M (2016) Glioblastoma multiforme targeted therapy: the chlorotoxin story. J Clin Neurosci 33:52-58. https ://doi.org/10.1016/j.jocn.2016.04.012

Cruz Olivo EA, Santos D, de Lima ME et al (2017) Antibacterial effect of synthetic peptide LyeTxI and LyeTxI/beta-cyclodextrin association compound against planktonic and multispecies biofilms of periodontal pathogens. J Periodontol 88:e88-e96. https ://doi.org/10.1902/jop.2016.160438

Deslouches B, Di YP (2017) Antimicrobial peptides with selective antitumor mechanisms: prospect for anticancer applications. Oncotarget 8:46635-46651. https://doi.org/10.18632/oncot arget. 16743

Esmaeili M, Stensjoen AL, Berntsen EM et al (2018) The direction of tumour growth in glioblastoma patients. Sci Rep 8:1199. https:// doi.org/10.1038/s41598-018-19420-z

Eum K-H, Lee M (2011) Targeting the autophagy pathway using ectopic expression of Beclin 1 in combination with rapamycin in drug-resistant v-Ha-ras-transformed NIH 3 T3 cells. Mol Cells 31:231-238. https://doi.org/10.1007/s10059-011-0034-6

Felício MR, Silva ON, Gonçalves S et al (2017) Peptides with dual antimicrobial and anticancer activities. Front Chem 5:5. https:// doi.org/10.3389/fchem.2017.00005

Galluzzi L, Vanden Berghe T, Vanlangenakker N et al (2011) Programmed necrosis from molecules to health and disease. Int Rev Cell Mol Biol 289:1-35. https://doi.org/10.1016/B978-0-12386039-2.00001-8

Galluzzi L, Buque A, Kepp O et al (2015) Immunological effects of conventional chemotherapy and targeted anticancer agents. Cancer Cell 28:690-714. https://doi.org/10.1016/j.ccell.2015.10.012

Gartlon J, Kinsner A, Bal-Price A et al (2006) Evaluation of a proposed in vitro test strategy using neuronal and non-neuronal cell systems for detecting neurotoxicity. Toxicol Vitro 20:1569-1581. https:// doi.org/10.1016/j.tiv.2006.07.009

Gewirtz DA (2014) An autophagic switch in the response of tumor cells to radiation and chemotherapy. Biochem Pharmacol 90:208211. https://doi.org/10.1016/j.bcp.2014.05.016

Gomes JAS, Bahia-Oliveira LMG, Rocha MOC et al (2003) Evidence that development of severe cardiomyopathy in human Chagas' disease is due to a Th1-specific immune response. Infect Immun 71:1185-1193

Grimberg J, Nawoschik S, Belluscio L et al (1989) A simple and efficient non-organic procedure for the isolation of genomic DNA from blood. Nucleic Acids Res 17:8390

Huang Y-B, Wang X-F, Wang H-Y et al (2011) Studies on mechanism of action of anticancer peptides by modulation of hydrophobicity within a defined structural framework. Mol Cancer Ther 10:416426. https://doi.org/10.1158/1535-7163.MCT-10-0811

Kanematsu S, Uehara N, Miki H et al (2010) Autophagy inhibition enhances sulforaphane-induced apoptosis in human breast cancer cells. Anticancer Res 30:3381-3390

Kim WS, Kim H, Kwon KW et al (2016) Cisplatin induces tolerogenic dendritic cells in response to TLR agonists via the abundant production of IL-10, thereby promoting Th2- and Tr1-biased T-cell immunity. Oncotarget 7:33765-33782. https://doi.org/10.18632/ oncotarget. 9260

Lee M, Jeon YJ (2001) Paclitaxel-induced immune suppression is associated with NF-kappaB activation via conventional PKC isotypes in lipopolysaccharide-stimulated $70 \mathrm{Z} / 3$ pre-B lymphocyte tumor cells. Mol Pharmacol 59:248-253. https://doi.org/10.1124/ mol.59.2.248

Liu S, Yang H, Wan L et al (2013) Penetratin-mediated delivery enhances the antitumor activity of the cationic antimicrobial peptide Magainin II. Cancer Biother Radiopharm 28:289-297. https://doi.org/10.1089/cbr.2012.1328

Liu Q, Zhao H, Jiang Y et al (2016) Development of a lytic peptide derived from BH3-only proteins. Cell Death Discov 2:16008. https://doi.org/10.1038/cddiscovery.2016.8

Marqus S, Pirogova E, Piva TJ (2017) Evaluation of the use of therapeutic peptides for cancer treatment. J Biomed Sci 24:21. https:// doi.org/10.1186/s12929-017-0328-X

Matassov D, Kagan T, Leblanc J, Sikorska M, Zakeri Z (2004) Measurement of apoptosis by DNA fragmentation. In: Brady HJM (ed) Apoptosis methods and protocols. Methods in molecular biology, vol 282. Humana Press, London

Meira DD, Marinho-Carvalho MM, Teixeira CA et al (2005) Clotrimazole decreases human breast cancer cells viability through alterations in cytoskeleton-associated glycolytic enzymes. Mol Genet Metab 84:354-362. https://doi.org/10.1016/j.ymgme.2004.11.012

Mellinghoff IK, Gilbertson RJ (2017) Brain tumors: challenges and opportunities to cure. J Clin Oncol 35:2343-2345. https://doi. org/10.1200/JCO.2017.74.2965

Melo-Lima S, Celeste Lopes M, Mollinedo F (2014) Necroptosis is associated with low procaspase- 8 and active RIPK1 and -3 in human glioma cells. Oncoscience 1:649-664. https://doi. org/10.18632/oncoscience.89

Mizushima N, Yoshimori T, Levine B (2010) Methods in mammalian autophagy research. Cell 140:313-326. https://doi.org/10.1016/j. cell.2010.01.028

Moore SJ, Leung CL, Norton HK, Cochran JR (2013) Engineering agatoxin, a cystine-knot peptide from spider venom, as a molecular probe for in vivo tumor imaging. PLoS ONE 8:e60498. https:// doi.org/10.1371/journal.pone.0060498

Mosmann T (1983) Rapid colorimetric assay for cellular growth and survival: application to proliferation and cytotoxicity assays. J Immunol Methods 65:55-63

Nicoletti I, Migliorati G, Pagliacci MC et al (1991) A rapid and simple method for measuring thymocyte apoptosis by propidium iodide staining and flow cytometry. J Immunol Methods 139:271-279

Nicoletti NF, Erig TC, Zanin RF et al (2017) Pre-clinical evaluation of voltage-gated calcium channel blockers derived from the spider P. nigriventer in glioma progression. Toxicon 129:58-67. https:// doi.org/10.1016/j.toxicon.2017.02.001

O'Brien J, Wilson I, Orton T, Pognan F (2000) Investigation of the Alamar Blue (resazurin) fluorescent dye for the assessment of mammalian cell cytotoxicity. Eur J Biochem 267:5421-5426

Ojha R, Bhattacharyya S, Singh SK (2015) Autophagy in cancer stem cells: a potential link between chemoresistance, recurrence, and metastasis. BioRes Open Access 4:97-108. https://doi. org/10.1089/biores.2014.0035

Pane K, Durante L, Crescenzi O et al (2017) Antimicrobial potency of cationic antimicrobial peptides can be predicted from their amino acid composition: application to the detection of "cryptic" antimicrobial peptides. J Theor Biol 419:254-265. https://doi. org/10.1016/j.jtbi.2017.02.012

Pasparakis M, Vandenabeele P (2015) Necroptosis and its role in inflammation. Nature 517:311-320. https://doi.org/10.1038/natur e14191

Perez-Pitarch A, Guglieri-Lopez B, Nacher A et al (2017) Impact of undernutrition on the pharmacokinetics and pharmacodynamics of anticancer drugs: a literature review. Nutr Cancer 69:555-563. https://doi.org/10.1080/01635581.2017.1299878

Pietkiewicz S, Schmidt JH, Lavrik IN (2015) Quantification of apoptosis and necroptosis at the single cell level by a combination of Imaging Flow Cytometry with classical Annexin V/propidium iodide staining. J Immunol Methods 423:99-103. https://doi. org/10.1016/j.jim.2015.04.025 
Pineda SS, Undheim EAB, Rupasinghe DB et al (2014) Spider venomics: implications for drug discovery. Fut Med Chem 6:1699-1714. https://doi.org/10.4155/fmc.14.103

Reis PVM, Boff D, Verly RM et al (2018) LyeTxI-b, a synthetic peptide derived from Lycosa erythrognatha spider venom, shows potent antibiotic activity in vitro and in vivo. Front Microbiol 9:667. https://doi.org/10.3389/fmicb.2018.00667

Rooj AK, McNicholas CM, Bartoszewski R et al (2012) Glioma-specific cation conductance regulates migration and cell-cycle progression. J Biol Chem 287:4053-4065. https://doi.org/10.1074/ jbc.M111.311688

Santos DM, Verly RM, Pilo-Veloso D et al (2010) LyeTx I, a potent antimicrobial peptide from the venom of the spider Lycosa erythrognatha. Amino Acids 39:135-144. https://doi.org/10.1007/ s00726-009-0385-x

Simon P, Langdon S (2003) Viable cell counting using trypan blue. In: Simon P (ed) Cancer cell culture methods protocols. Humana press, Langdon, p 26

Su Z, Yang Z, Xie L et al (2016) Cancer therapy in the necroptosis era. Cell Death Differ 23:748-756. https://doi.org/10.1038/cdd.2016.8

Sun W, Bao J, Lin W et al (2016) 2-Methoxy-6-acetyl-7-methyljuglone (MAM), a natural naphthoquinone, induces NO-dependent apoptosis and necroptosis by $\mathrm{H}_{2} \mathrm{O}_{2}$-dependent $\mathrm{JNK}$ activation in cancer cells. Free Radical Biol Med 92:61-77. https://doi.org/10.1016/j. freeradbiomed.2016.01.014

Sun Y, Zhai L, Ma S et al (2018) Down-regulation of RIP3 potentiates cisplatin chemoresistance by triggering HSP90-ERK pathway mediated DNA repair in esophageal squamous cell carcinoma. Cancer Lett. https://doi.org/10.1016/j.canlet.2018.01.022

Swartz AM, Batich KA, Fecci PE, Sampson JH (2015) Peptide vaccines for the treatment of glioblastoma. J Neurooncol 123:433440. https://doi.org/10.1007/s11060-014-1676-y

Thompson RF, Walker M, Siebert CA et al (2016) An introduction to sample preparation and imaging by cryo-electron microscopy for structural biology. Methods (San Diego, Calif) 100:3-15. https:// doi.org/10.1016/j.ymeth.2016.02.017

Tran S-L, Puhar A, Ngo-Camus M, Ramarao N (2011) Trypan blue dye enters viable cells incubated with the pore-forming toxin HlyII of Bacillus cereus. PLoS ONE 6:e22876. https://doi.org/10.1371/ journal.pone.0022876
Vandenabeele P, Galluzzi L, Vanden Berghe T, Kroemer G (2010) Molecular mechanisms of necroptosis: an ordered cellular explosion. Nat Rev Mol Cell Biol 11:700

Wallberg F, Tenev T, Meier P (2016) Analysis of apoptosis and necroptosis by fluorescence-activated cell sorting. Cold Spring Harb Protoc 2016:pdb.prot087387. https://doi.org/10.1101/pdb.prot087387

Wang X, Wang G (2016) Insights into antimicrobial peptides from spiders and scorpions. Protein Pept Lett 23:707-721

Wang C, Tian L-L, Li S et al (2013) Rapid cytotoxicity of antimicrobial peptide tempoprin-1CEa in breast cancer cells through membrane destruction and intracellular calcium mechanism. PLoS ONE 8:e60462. https://doi.org/10.1371/journal.pone.0060462

Wei J-W, Cai J-Q, Fang C et al (2017) Signal peptide peptidase, encoded by HM13, contributes to tumor progression by affecting EGFRvIII secretion profiles in glioblastoma. CNS Neurosci Ther 23:257-265. https://doi.org/10.1111/cns.12672

William D, Walther M, Schneider B et al (2018) Temozolomideinduced increase of tumorigenicity can be diminished by targeting of mitochondria in in vitro models of patient individual glioblastoma. PLoS ONE 13:e0191511. https://doi.org/10.1371/ journal.pone. 0191511

Wlodkowic D, Skommer J, Darzynkiewicz Z (2011) Rapid quantification of cell viability and apoptosis in B-cell lymphoma cultures using cyanine SYTO probes. Methods Mol Biol 740:81-89. https ://doi.org/10.1007/978-1-61779-108-6_10

Xu B, Xu M, Tian Y et al (2017) Matrine induces RIP3-dependent necroptosis in cholangiocarcinoma cells. Cell Death Discov 3:16096. https://doi.org/10.1038/cddiscovery.2016.96

Yu T, Malugin A, Ghandehari H (2011) The impact of silica nanoparticle design on cellular toxicity and hemolytic activity. ACS Nano 5:5717-5728. https://doi.org/10.1021/nn2013904

Zabeo D, Cvjetkovic A, Lässer C et al (2017) Exosomes purified from a single cell type have diverse morphology. J Extracell Ves 6:1329476. https://doi.org/10.1080/20013078.2017.1329476

Zhao H, Wang C, Lu B et al (2016) Pristimerin triggers AIF-dependent programmed necrosis in glioma cells via activation of JNK. Cancer Lett 374:136-148. https://doi.org/10.1016/j.canle t.2016.01.055 